\title{
Application of Physically Based Semi-Distributed Hec-Hms Model for Flow Simulation in Tributary Catchments of Kaohsiung Area Taiwan
}

Fiaz Hussain

Department of Agricultural Engineering, PMAS-Arid Agriculture University, Rawalpindi, Pakistan

Ray-Shyan Wu

Department of Civil Engineering, National Central University, Chung-Li, Taiwan, raywu@ncu.edu.tw

Kai-Chun Yu

Department of Civil Engineering, National Central University, Chung-Li, Taiwan

Follow this and additional works at: https://jmstt.ntou.edu.tw/journal

Part of the Fresh Water Studies Commons, Marine Biology Commons, Ocean Engineering Commons, Oceanography Commons, and the Other Oceanography and Atmospheric Sciences and Meteorology Commons

\section{Recommended Citation}

Hussain, Fiaz; Wu, Ray-Shyan; and Yu, Kai-Chun (2021) "Application of Physically Based Semi-Distributed Hec-Hms Model for Flow Simulation in Tributary Catchments of Kaohsiung Area Taiwan," Journal of Marine Science and Technology. Vol. 29: Iss. 1, Article 4.

DOI: $10.51400 / 2709-6998.1003$

Available at: https://jmstt.ntou.edu.tw/journal/vol29/iss1/4

This Research Article is brought to you for free and open access by Journal of Marine Science and Technology. It has been accepted for inclusion in Journal of Marine Science and Technology by an authorized editor of Journal of Marine Science and Technology. 


\title{
Application of Physically Based Semi-Distributed HEC-HMS Model for Flow Simulation in Tributary Catchments of Kaohsiung Area Taiwan
}

\author{
Fiaz Hussain ${ }^{a, b}$, Ray-Shyan $W^{a, *}$, Kai-Chun $\mathrm{Yu}^{\mathrm{a}}$

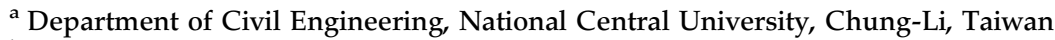 \\ ${ }^{\mathrm{b}}$ Department of Agricultural Engineering, PMAS-Arid Agriculture University, Rawalpindi, Pakistan
}

\begin{abstract}
Hydrologic modeling is a commonly used tool to understand the rainfall-runoff processes of gauged and ungauged catchments for proper quantitative estimation of water resources availability. In the present study, an attempt is made to simulate surface runoff using a physically based semi-distributed hydrological (HEC-HMS) model for four local-scale tributary catchments of Kaohsiung area Taiwan. The input physical parameters of the model were calculated and preprocessed in HEC-GeoHMS based on digital elevation model (DEM), land use, soil and hydro-meteorological data. The model performance was satisfactory with Nash Sutcliffe Efficiency (NSE) $=0.51$ to 0.86 and the coefficient of determination $\left(R^{2}\right)=0.63$ to 0.86 during calibration (2016-2017) and validation (2018) period based on the selected loss, transform and flow routing, Soil Conservation Service Curve Number (SCS-CN), Soil Conservation Service Unit Hydrograph (SCS-UH) and Muskingum methods, respectively. The comparison of the observed and simulated hydrographs showed that the model is appropriate for hydrological simulations in Kaohsiung area. Therefore, the model was applied using calibrated parameters (CN and Ia) in ungauged Meinong creek catchment. The comparative results between the maximum design flow and the average simulated monsoonal flows verified that HEC-HMS model can synthesize hydrologic processes and phenomena for both wet and dry seasons. It is concluded that the developed methodology can be applied in ungauged catchments for water resources management and planning purposes under future climate scenarios that will help hydrologists to understand the efficiency and application of HEC-HMS model in rainfall-runoff modeling.
\end{abstract}

Keywords: HEC-HMS, Event and continuous modeling, Rainfall-runoff, Simulation

\section{Introduction}

B usiness-as-usual water management is no match for the emerging global water crisis driven by climate change and population growth. According to Water Resources Agency (WRA), climate change has adversely affected Taiwan during recent years, with the presenting effects as increased temperatures, a decreased number of rainy days, the frequent variations of dry and wet seasons, and an increased number of extreme events with high rainfall intensity [1]. As a result, regional and catchment scale hydrological uncertainties has increased which led to an increasingly severe water supply crisis. During the wet season, the high-intensity rainfall manifests in typhoon and flood periods. The uneven spatiotemporal rainfall distribution and high runoff power due to steep slopes scour large amounts of sediment and reduce reservoirs storage. During the dry season, a significant reduction in streamflow is always challenging for 
regulating water use and supply. In order to alleviate water shortages, this leads to increased dependence on existing water resources for agriculture and river ecosystems that may affect ecological habitats in the upstream area. These factors also have relative effects on groundwater resources and may increase difficulties in the utilization and management of groundwater resources [2].

Globally, the simulation and prediction of rainfallrunoff flows in gauged and ungauged catchments is considered vital for understanding the hydrological problems and practical applications. Watershed hydrologic modeling for rainfall-runoff complex relationship is essential to quantify water resources for effective system management, analysis and design. The rainfall-runoff modeling is a helpful tool for water resources managers and engineers to manage water resources projects (design, construction and operation) and to mitigate floods and drought consequences. However, watershed modeling not only needs adequate and large set of spatiotemporal data (e.g., topography, land use/ covers, soils, rainfall, and flow monitoring data), it also needs a sound understanding of rainfall-runoff processes of a particular watershed for accurate estimation of runoff quantity, flood and drought management and overall assessment of the watershed response as a part of strategic and master planning [3].

The selection of modeling approach normally depends on purpose, data availability and ease of use [4] but the challenge is the choice of rainfallrunoff model that can accurately simulate hydrologic process under various climate conditions and available data. Generally, stochastic and deterministic hydrological models are available based on output partial randomness and no randomness, respectively. The deterministic models further categorized into lumped and distributed models while the distributed models further classified into physically based semi-distributed and fully distributed models depends on distribution description. Distributed hydrological models have been found to be suitable for simulating a rainfall-runoff process in gauged watersheds successfully for the last four decades, but the representation of flow in ungauged watershed remains a challenge among the hydrologist [5]. In the ungauged case, it is generally accepted that physically based hydrological models are a better choice [6]. physically based models are distributed and truly representative of the real hydrological processes with confident parameter quantification in catchment. In ungauged catchment, the model parameters are calculated from the existing climatic and physiographic characteristics of the catchment. The parameters of physically based models are quantified using measurable physical properties, avoiding the necessity of calibration against observed data. HECHMS model is a process based physical model with parameters to be estimated directly from field data and remote sensing data. The continuous and event based hydrological modeling of gauged and ungauged dendritic watershed systems has been performed using HEC-HMS model in different regions. [7] confidently validated the HEC-HMS model in Hoovinahole gauged watershed, India, and applied reliable calibrated parameters to neighbor ungauged Doddahalla agriculture watershed for rainfallrunoff modeling and estimation of stream flow and peak flow. [8] simulated the flow regimes at ungauged sites in the southern California using HECHMS rainfall-runoff modeling where the HEC-HMS model was first calibrated and validated at different gauge locations and then HEC-HMS model associated with the most proximal gauge was assigned to each ungauged site. Hydrological models mainly depends on the input data, hydrological parameter and structure of the model, particularly modeling in ungauged catchment using the climate and physiographic characteristics such as topography, land use, soil, vegetation, and climate data $[9,10]$. Similarly, for ungauged catchment-flow simulations, the HEC-HMS underestimates high flows during the early wet season, and overestimates low flows in the late dry season [11]. Ungauged river understanding and modelling for water resource management and planning such as the Keseke River catchment in South Ome River basin by using hydrological model (HEC-HMS) with GIS and remote sensing techniques can provide important information and analytical capability to hydrology and water resource assessment of the given river catchment [12].

Hydrological Engineering Center-Hydrological Modeling System (HEC-HMS) is a semi-distributed physically based hydrological modeling software developed by the US Army Corps of HEC [13]. HEC-HMS is an integrated physically based simulation tool for all hydrologic processes of dendritic watershed systems and parameters can be directly measured from watershed. Importantly it provides reasonable results, beyond the measurement of the parameters, since the model maintains the physical laws of the process.

It has been adopted in many hydrological studies with a wide variety of watershed types to simulate the rainfall-runoff processes (rainfall loss, direct 


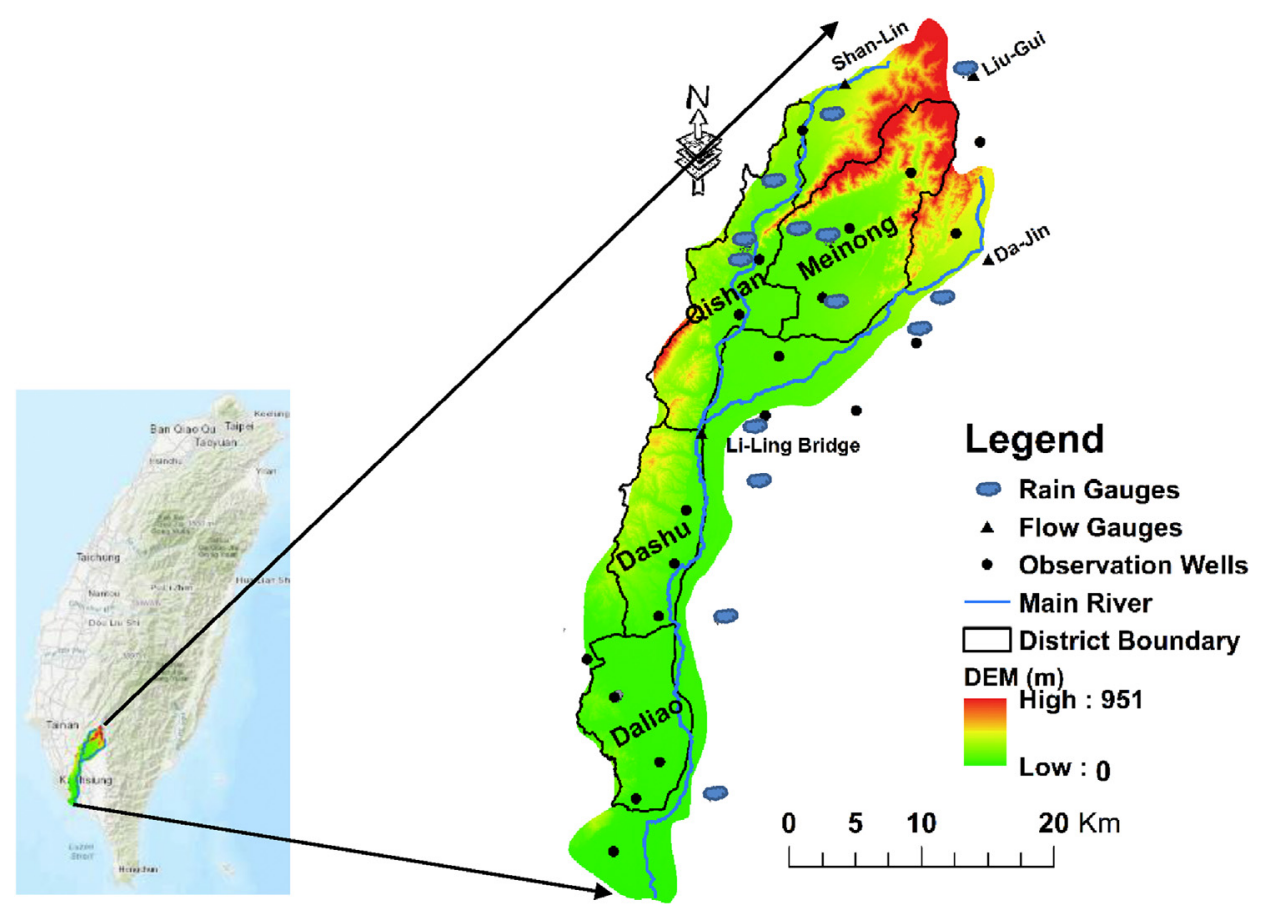

Fig. 1. Study area location map.

runoff, and routing) both in short and longtime events due to simple operation, and the choice of various models for each segment of the hydrologic cycle [14]. The HEC-HMS model has been used in many studies to analyze urban flooding, flood damage reduction, flood warning system planning, floodplain regulation, flood frequency, reservoir and system operation, environmental flows and river restoration, water supply planning, etc [15]. The HEC-HMS is a powerful commonly used physical tool to simulate hydrologic processes. Generally, in ungauged catchments, the choice of physically based hydrologic models is considered better and acceptable [6]. The application of continuous hydrologic model is considered reasonable because continuous modeling synthesizes hydrologic processes and phenomena (i.e., synthetic responses of the basin to a number of rain events and their cumulative effects) over a longer time period that includes both wet and dry conditions [3]. The runoff simulation by continuous rainfall-runoff models in ungauged catchments can also be used to estimate low flow [16]. The continuous and event based hydrological modeling of gauged and ungauged dendritic watershed systems has been performed using HEC-HMS model in different regions. To name a few, Mona Lake watershed Michigan [3]; Tonle Sap Lake Basin in Cambodia [11]; Lake Tana Basin, Ethiopia [17]; Simly dam watershed, Pakistan [18]; Abnama Watershed, Iran [19]; Qinhuai River basin,
China [20]; Al-Zarqa Basin in Jordan [21]; Oil Palm Catchment, Malaysia [22]; various catchments in Taiwan [23-25]. Most of these studies clearly indicated that the results of the model simulation were location specific, in that different combinations of a model set containing the loss methods, runoff transform methods, routing and baseflow separation techniques were found to respond variably.

In this study, we applied physically based semidistributed continuous hydrological model, HECHMS for the calibration and validation of direct runoff at a gauged location (Li-Ling Bridge) Kaoping River and then the calibrated model was applied to estimate the runoff potential in ungauged Meinong creek catchment. Although the HEC-HMS model has been tested and calibrated at a global scale, little effort has been made in ungauged creek catchments of southern Taiwan [26]. The Water Resources Agency has also reported the significant decreasing trend of streamflow in southern Taiwan under most adverse future rainfall scenario [2]. This will further stress the future water resources and may create several water related issues in southern Taiwan. Therefore, there is a need to enhance water resource regulation in the region under current climate change conditions. The objectives of the current study are (1) to develop the physically based semidistributed rainfall-runoff model (2) to calibrate and validate the model and fix the corresponding calibrated values for future hydrological investigations 


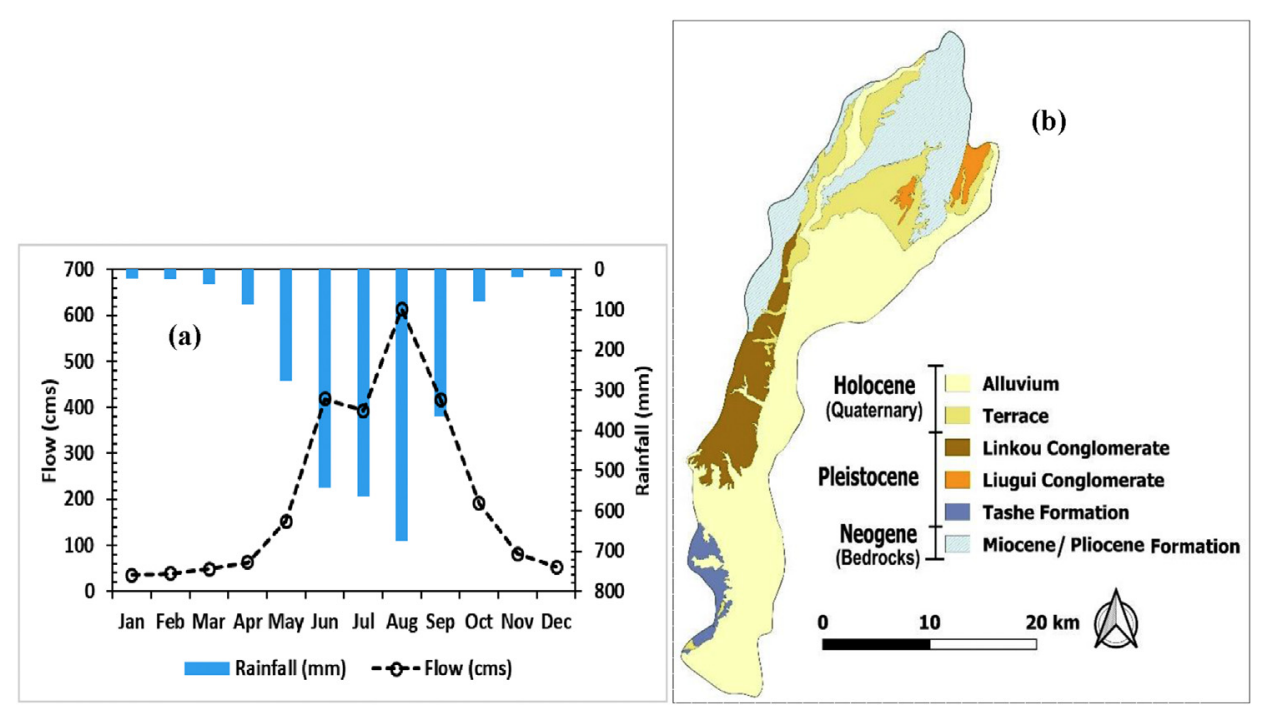

Fig. 2. (a) The average monthly rainfall and flow data (1991-2018); (b) the geological information of study area.

and (3) to apply the calibrated model to assess the runoff potential of ungauged creek catchment. This paper enhance the capacity and capability of physically based HEC-HMS model for synthesizing the hydrological processes at ungauged catchment during dry and wet seasons.

\section{Study area description}

This study is performed in four tributary catchments as local-scale sites of the Meinong river, the Qishan river and the Kaoping river flowing east of district Dashu and Daliao. The four districts (Qishan, Meniong, Dashu and Daliao) are located in Kaoping river delta. The demarcation of study region for hydrological modeling is done in such a way that it includes four districts along with main river and its tributaries as shown in Fig. 1. These cities are highly urbanized and are under serious threats of water management. The extreme rainfall conditions $\left(500 \mathrm{~mm} \mathrm{~d}^{-1}\right)$ often create pluvial flooding. The average annual rainfall of Kaoping river basin is approximately $2502 \mathrm{~mm}$, while average annual flow at Liling Bridge is $210 \mathrm{cms}$. The summer rainfall is the main source of water that comes from the torrential rains or tropical low pressures hitting. Around $69 \%$ of the rainfall occurred in May to October months while due to uneven spatiotemporal rainfall distributions the intensity varies greatly. There is a marked difference in the river flow between the summer season (peak flow) and the winter season (low flow) [27] as presented in Fig. $2 \mathrm{a}$. The average monthly rainfall and flow of 26-year (1991-2018) data indicated that main rainy season lasting from June to September, and the main dry season extending from October to March. The fluctuation of average monthly rainfall during 1991-2018 has become much more extreme between June and August while, during dry season the rainfall has been far below the average [28].

The Kaoping river begins in mountainous areas in the upper reaches, flows into a flood plain in the midstream, and ends in an alluvial estuary in the lower reaches. The surface and groundwater resources of that area have significant importance for the domestic, commercial and agricultural water system. More importantly, the topography and geology of the area is relatively different from the alluvial formation of Pingtung County. The outcropped formations are shown in Fig. $2 b$. Generally, the formations are sedimentary rocks and the ages vary from Holocene and Pleistocene (Quaternary) to Pliocene and Miocene (Neogene). The youngest lithology is the Holocene (less than 11,700 years) which consist of deposits from the Western Foothills and Central Range brought by the modern channel to the lower elevation. The Holocene alluvium and terrace deposits consist of gravel, sand and mud. The Pleistocene formations (between 11,700 and 2.58 million years) include Linkou and Liugui conglomerates and Tashe formation. The Linkou conglomerate is mainly clastic support while Liugui conglomerate is matrix support. Tashe formation comprised with thick mudstones with interbedded sandstone and conglomerates. The Pleistocene formations are weakly cemented and usually are not heavily jointed. The hydraulic conductivity is slightly lower than the Holocene sediments but generally higher than the Neogene (Miocene to Pliocene) bedrocks. These geological 
Table 1. Data type, source and description used in this study.

\begin{tabular}{|c|c|c|}
\hline Data Type & Source & Resolution \\
\hline $\begin{array}{l}\text { Digital Elevation } \\
\text { Model (DEM) }\end{array}$ & Ministry of Interior, Taiwan (Open Data) & $20 \mathrm{~m} \times 20 \mathrm{~m}$ (raster data) \\
\hline Landuse map & $\begin{array}{l}\text { National Land Surveying and Mapping Center, } \\
\text { Ministry of Interior, Taiwan (NLSC) }\end{array}$ & Polygon shapefile (vector data) \\
\hline Soil map & [32] & Poly \\
\hline Rainfall gauge data & Water Resource Agency (WRA), Ministry of Econc & Hourly rainfall data \\
\hline Streamflow data & Water Resource Agency (WRA), Ministry of Economic Affairs, (MOEA) & Hourly stream flow data (2016-2018) \\
\hline Geology data & Central Geological Survey (CGS), Ministry of Economic Affairs (MOEA) & Polygon shapefile (vector data) \\
\hline
\end{tabular}

features provide helpful information related to groundwater flow movement and contribution.

According to [27]; the upstream Meinong and Qishan districts soil texture is very poor keel, full of gravel and small stones that create easy infiltration of surface water into the ground. The groundwater flows slowly between the interstices of soil layers and create the abundant ground water system [27]. The Meinong creek catchment (MCC) has an area of $114 \mathrm{~km}^{2}$ with river length of $28.5 \mathrm{~km}$ located on the upper reaches of Kaoping river. The MCC surrounded with hills in the west, north, and east sides. The rainfall-runoff is the main source of water in this creek. According to [29]; the maximum design discharge of MCC at the outlets of Shuāng, Shulidi, Qiāngziliáo, and Meinong creeks is $445 \mathrm{cms}, 720$ $\mathrm{cms}, 770 \mathrm{cms}$ and $860 \mathrm{cms}$, respectively while 980 $\mathrm{cms}$ at the confluence with the Qishan creek.

Qishan river is the largest tributary $(\mathrm{L}=117 \mathrm{~km}, \mathrm{~A}$ $=842 \mathrm{~km}^{2}$ ) of Kaoping river. It originated at the elevation of about 2,700 $\mathrm{m}$ on the southwest slope of the main peak of Yùshān mountain. After passing through Namaxia, Jiaxian and Shanlin districts, it flows through Qishan district and at the mouth of Lingkou, it is renamed as Kaoping river. The annual average daily flow is $30 \mathrm{cms}$ and the annual runoff is about $885 \mathrm{MCM}$ at Nanfeng bridge. Qishan creek catchment (QCC) area is $94.61 \mathrm{~km}^{2}$ with creek length of $31.2 \mathrm{~km}$. Most area is hilly and due to climate and the quality of soil, the bananas production is high and has a fame of "Banana Kingdom". The flow coming from upstream is measured at the Shanlin bridge. Dashu creek catchment $\left(66.98 \mathrm{~km}^{2}\right)$ is in the southwest of Kaohsiung, adjacent to the Lingkou of Qishan district in the north, facing Kaoping river across Pingtung County. The area is mainly mountainous comprised of continuation of Central Mountain Range and the Neimen Hills. The main flowing river beside Dashu district is Kaoping river having creek length of 19.74 $\mathrm{km}$. Daliao creek catchment comprised of $71.04 \mathrm{~km}^{2}$ suburban area and $19.17 \mathrm{~km}$ long creek.

\section{Materials and methods}

In this study, the physically based semi-distributed continuous hydrological model HEC-HMS was calibrated and validated on an hourly basis at LiLing bridge stream flow gauge. While the inflows are also considered as boundary inflow sources at Shan-Lin bridge, Liu-Gui, Da-Jin bridge and SanTimen locations. The flow at Li-Ling bridge is contributed from all the upstream sub-basins. After calibration of hydrological parameters, we applied the model for the same period in each creek catchments to determine flow hydrographs. Keeping in view the main objectives of the study, the following methodology was adopted to simulate the flows.

\subsection{Flow simulation using physically based semi- distributed hydrological model}

\subsubsection{Data acquisition}

The datasets required for rainfall-runoff hydrological modeling include hydro-meteorological (rainfall and stream flow) and physiographic (digital elevation model, land use/cover and soil type) databases. The necessary input data was acquired from government agencies. $20 \mathrm{~m} \times 20 \mathrm{~m}$ digital elevation model (DEM) was collected from an open data source of Ministry of Interior, Taiwan. The DEM data was used to extract the physiographic characteristics of study area such as slope, catchment analysis, HEC-HMS initial parameters (basin area, river slope and length), terrain processing etc. The shapefile of land use and land cover data were collected from [30,31]; Taiwan. That data was further processed and used for the generation of $\mathrm{CN}$ raster file to use in HEC-HMS model. The shapefile of soil data was collected from [32] Taiwan and further processed to acquire information about hydrologic 


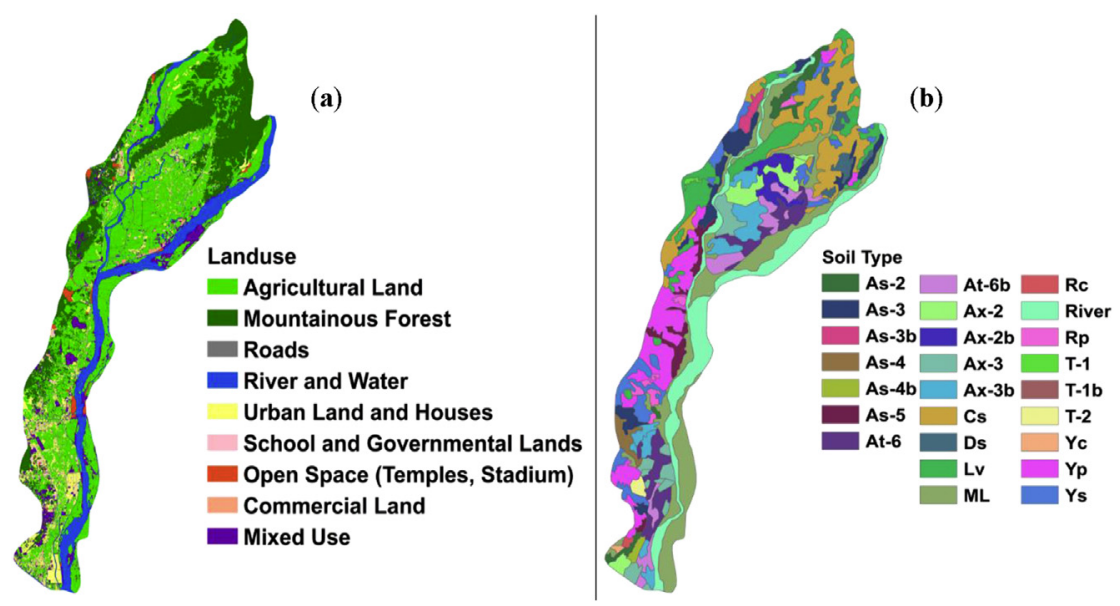

Fig. 3. Physiographic data set of the study area (a) land use-land cover classification (b) soil types.

soil group classification. The hourly data of precipitation and streamflow at the gauged location for the years 2016-2018 was obtained from [33] while the geology data were obtained from [34] Ministry of Economic Affairs Taiwan as illustrated in Table .1.

The maps of physiographic data are shown in Fig. 3. The elevation of the study area varies from 0 to $951 \mathrm{~m}$ with steep slope in the northern mountains. The maximum slope range up to $65 \%$. The soil type is a mixed form. It consists of sandstone-shale calcareous and non-calcareous alluvium soils with some imperfect drained condition as represented by "As" soils in Map. Similarly, "At" soil comprised of slate calcareous alluvial nature. While "Ax" type soils are sandstone-shale-slate non-calcareous and calcareous alluvial soils. "Cs and Ds" soils are sandstone-shale colluvium pale and darkish soils, respectively. "Lv" soil is known as precipitous area. ML is the miscellaneous land including riverbeds and sand dunes while Rc and Rp are limestone and diluvium red soils, respectively. The " $T$ " soils are Taiwan clay soils and " $Y$ " soils are yellow soils having limestone, diluvium and sandstone-shale material. The land use and land cover consist of $42.5 \%$ agricultural land and $24.3 \%$ is mountainous forest. The river/water area is $12.6 \%$ and housing area with commercial lands, temples, open spaces, government land, schools etc. comprises of $10.5 \%$ of total study area. Mixed-use land takes $6.7 \%$ and roads cover $3.4 \%$ of the study area.

Physical parameters based hydrologic modeling of catchment is suitable technique for simulating a rainfall-runoff process and flow conditions in wet and dry seasons. The physiographic features and parameters of catchments were delineated from spatial database and used for the flow simulation. The incorporation of spatially distributed physical parameters to simulate surface flow through watershed system in HEC-HMS model is the key attempt of this study. The systematic procedure adopted for this purpose is explained below.

\subsubsection{Hydrological models setup}

3.1.2.1. HEC-GeoHMS. The direct flow at the gauged location (Li-Ling bridge) is simulated using HECHMS [35] and the model setup is done in geospatial hydrological modeling (HEC-GeoHMS) extension of ArcGIS 10.1 [36]. HEC-GeoHMS efficiently and easily created the input files with hydrologic parameters for HEC-HMS model. HEC-GeoHMS geospatially analyze the DEM data and delineate subbasins and stream network. The terrain preprocessing module was completed using DEM data to get the hydrologically semi-distributed HECHMS model. The selected study area was delineated into multiple smaller subbasins with drainage network using the step-by-step procedure of preprocessing used in HEC-GeoHMS software (Fig. 4). The smaller threshold area $\left(0.50 \mathrm{~km}^{2}\right)$ is selected to define the stream and to get reasonable number of subbasins. In this way, the area is converted into semi-distribution condition for setting up the input parameters. After terrain preprocessing, the basin processing step was used to combine and/or divide subbasins with merge and split options. The subbasin and stream physical characteristics (such as basin slope and centroid, river length and slope, longest flow path etc.) were calculated using topographic features to estimate the subbasins hydrological parameters. This step is completed in stream and subbasin characteristics menu. For parameterizing the HEC-HMS model, the HEC-GeoHMS initially estimate the hydrological parameters such 


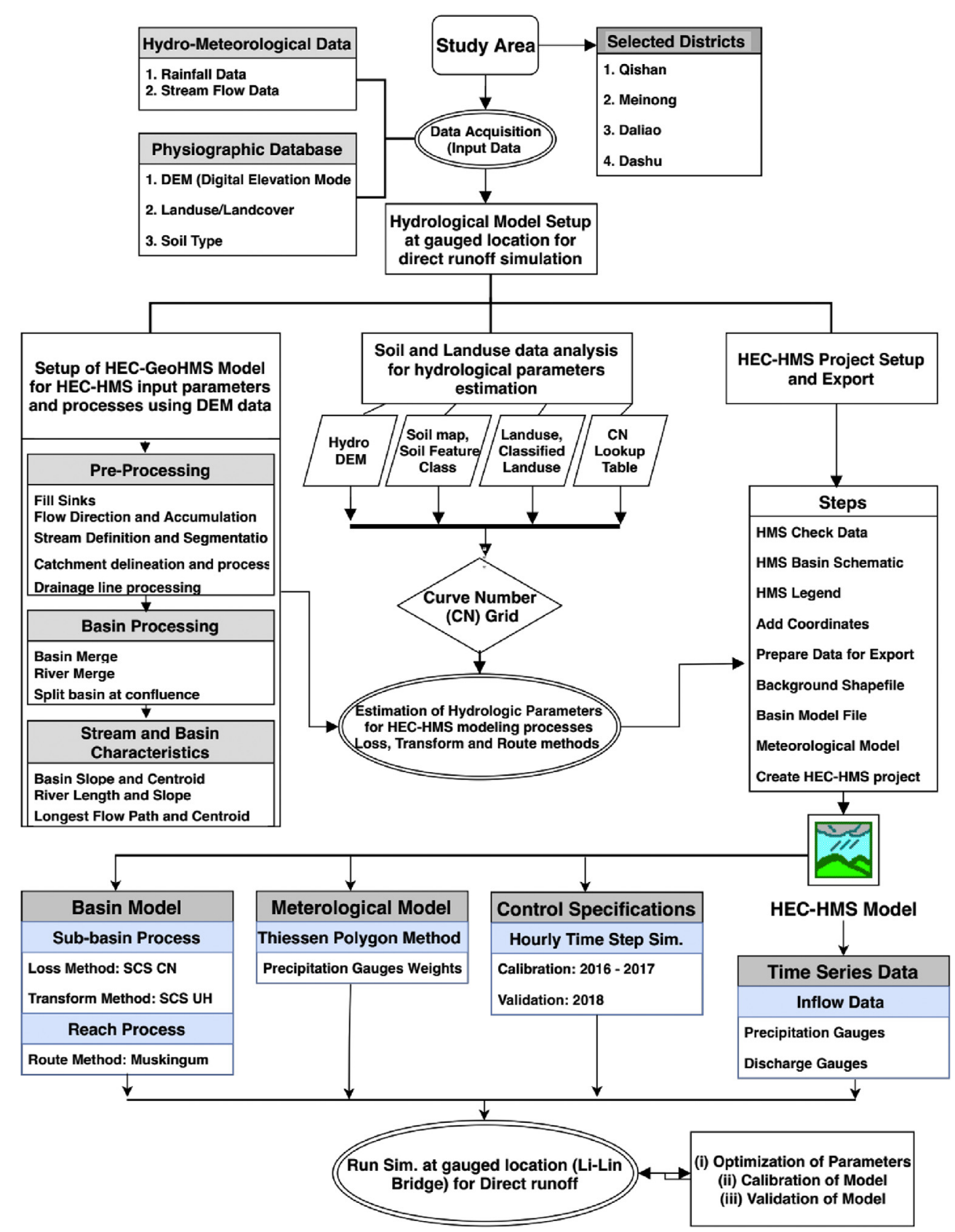

Fig. 4. Methodology used for hydrological modeling for the research.

as curve number $(\mathrm{CN})$, percent impervious area, time of concentration $(\mathrm{Tc})$, lag-time $\left(\mathrm{T}_{\mathrm{lag}}\right)$ etc. based on soil and landuse database and terrain analysis. In this study following HEC-HMS modeling methods were selected using HMS processes tool: subbasinloss method (SCS-CN); subbasin-transform method (SCS Unit Hydrograph) and river-route method (Muskingum). The initial parameters of SCS-CN loss method such as basin CN is computed using Generate $\mathrm{CN}$ Grid tool, the percent impervious area is calculated using land use data while initial abstraction is considered $20 \%$ of the potential maximum storage. The SCS Unit hydrograph transform method that needs only basin lag and its initial value was estimated using $\mathrm{CN}$ Lag method. The hydrologic project input files (basin/ meteorological files and background shapefile) of HEC-HMS model were created in Hydrological Modeling System menu. The meteorological model was created using Thiessen Polygon method. The 


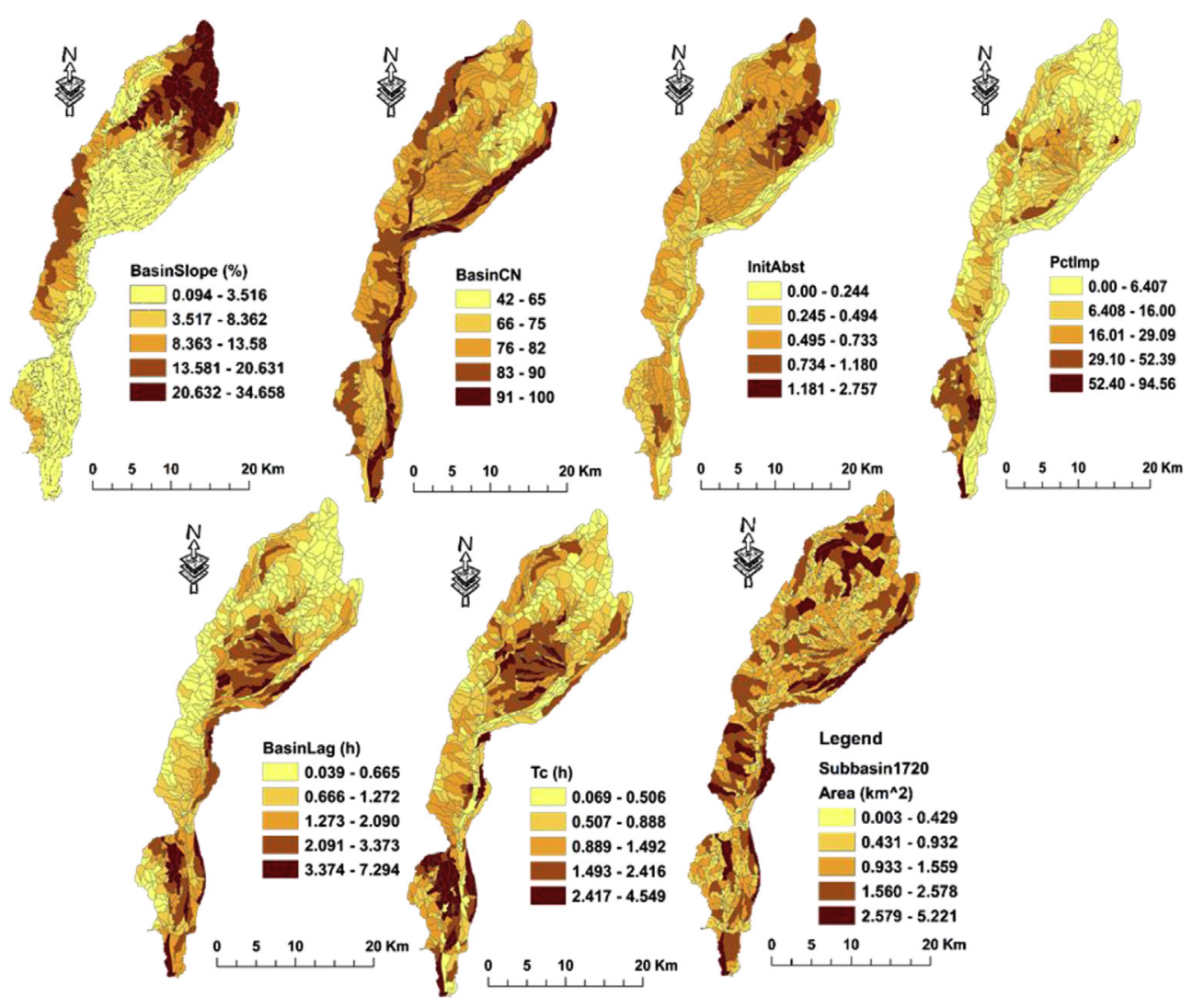

Fig. 5a. Range of basin scale initial parameters used in hydrological modeling.

precipitation weights were worked out in ArcGIS 10.1. After completing the basin and meteorological model setup with initial values, the HEC-GeoHMS complete project was imported to HEC-HMS 4.3 [37].

3.1.2.2. HEC-HMS model. It is a physically based semi-distributed hydrological model used to simulate rainfall-runoff processes. After setting up the model and parameters in HEC-GeoHMS, the basin model and features were taken as the background map file and imported to HEC-HMS 4.3. Flow chart methodology explain the steps used in HEC-HMS (Fig. 4). The direct flows were simulated on daily and hourly basis at the gauged location to calibrate and validate the model without considering the base flow. The daily flow simulation from 2016 to 2018 using initial setup and physical parameters before calibration is performed to check the parameters acceptability. After calibration of the model using (CN, Ia), it was applied to simulate the flows of each creek catchment. HEC-HMS model has four units. Basin model deals with subbasin and reach process. Total of 563 sub-basin were delineated to make the model semi-distributed and properly simulate the flows. Basin model comprised of physical attributes such as basin areas, river reach connectivity. Meteorological model has rainfall data which was worked out using Thiessen Polygon method and precipitation weights in HEC-GeoHMS. Control specifications deal with time to simulate and time interval. In this study, the model was used on hourly time step for calibration during 2016-2017 while the model validation was done for the year 2018 on hourly basis. The time series data is the fourth unit that deals with input data. In this study four upstream boundary inflows were forced in the model along with precipitation data inputs.

There are three HEC-HMS modeling processes such as loss, transform and routing method to simulate stream flows. The Soil Conservation Service Curve Number (SCS-CN), SCS Unit hydrograph, and Muskingum routing methods were selected as loss, transform and routing method, respectively.

SCS-CN loss method was used to estimate direct runoff based on $\mathrm{CN}$ and initial abstraction values (Ia) in $\mathrm{mm}$ for each sub-basin. Ia $=\alpha \mathrm{S}, \alpha=0.2$ as a standard assumption, and $S=$ soil retention in $\mathrm{mm}$ estimated using $\mathrm{CN}$. $\mathrm{CN}$ represents the combined 

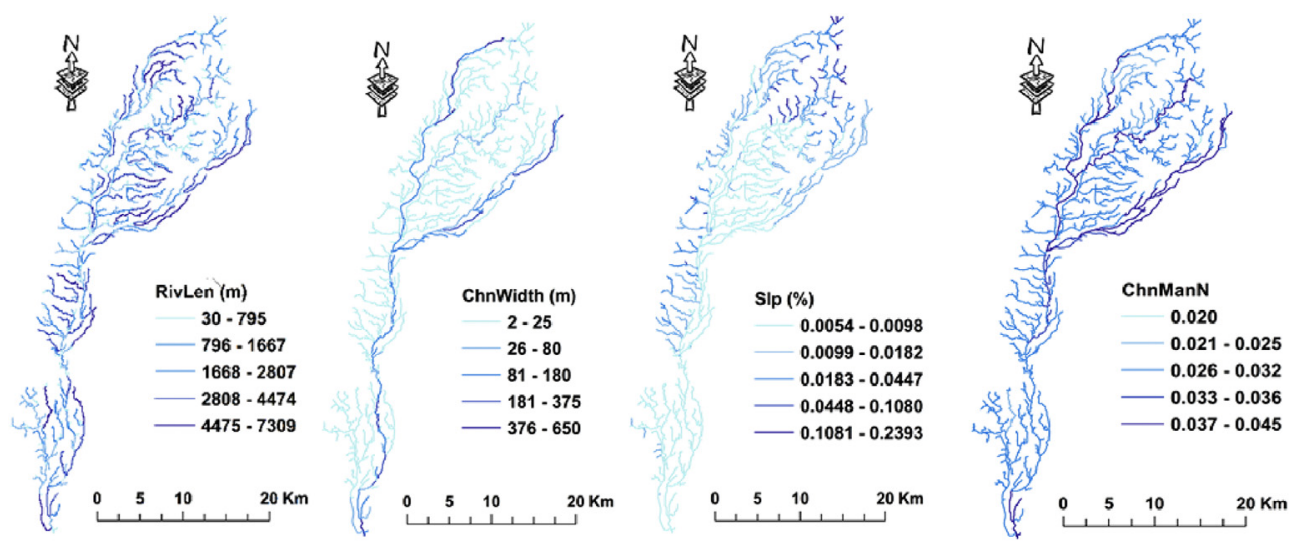

Fig. 5b. Range of river initial parameters used in hydrological modeling.

effects of the primary characteristics of the catchment area, including soil type, land use, and the previous moisture condition. The $\mathrm{CN}$ for water bodies is 100 while permeable soils with high infiltration rates have approximately 30 . In the curve number method, the runoff is directly proportional to the precipitation with an assumption that the runoff is produced after the initial abstraction of $20 \%$ of the potential maximum storage.

SCS unit hydrograph transform method deals with how to transform the excess precipitation to direct runoff. The basin lag time (the only input) for this method was calculated using $\mathrm{CN}$ lag equations (1) and (2).

$t_{\text {lag }}=\frac{\left(L^{0.8} \times(S+1)^{0.7}\right)}{1900 \times Y^{0.5}}$

$S=\frac{1000}{C N}-100$

where, $t_{\text {lag }}=$ basin lag time (h), $L=$ hydraulic length of the watershed (feet), $Y=$ basin slope (\%)

Muskingum routing method was selected to route the runoff through reach. The travel time $\mathrm{K}$ was assumed as Tc calculated by TR-55 method. The degree of storage $(x)$ was assumed 0.2 for all reaches.

\subsubsection{Estimation of hydrological parameters}

The initial values of hydrological parameters were computed in HEC-GeoHMS model using DEM data after basin pre-processing. The basin parameters for hydrological processes include basin slope, basin $\mathrm{CN}$, basin impervious area, basin initial abstraction loss, basin lag, and basin time of concentration. The reach parameters involve channel length, width, slope, and Manning's $\mathrm{n}$ values. Some initial parameters values were further optimized and calibrated to simulate the flow at Li-Ling gauged station. The initial parameters values are shown in Fig. $5 a$ and $5 b$.

\subsubsection{Model optimization, calibration and validation}

After setting up the parameters, the model simulation was calibrated at gauged location (Li-Ling bridge). The auto-optimization package was used to calibrate the parameters. In this study, initial abstraction (Ia) and curve number $(\mathrm{CN})$ were tuned to best possible match for the observed streamflow data. The model calibration was done with the univariate gradient optimization package and PeakWeighted Root Mean Square Error (PWRMS) objective function. The model was calibrated for period (2016-2017) while validation was performed for year 2018. The other watershed parameters were kept the same as used in initial condition except for Ia and $\mathrm{CN}$.

\subsubsection{Model performance evaluation}

The model performance was evaluated using three statistical evaluation techniques as given in equations (3)-(5). The coefficient of determination $\left(R^{2}\right)$ [38], which determines how well the modeled data is fit to observation data between the range $0 \leq R^{2} \leq 1$. Nash-Sutcliffe Efficiency (NSE) [39] indicates how well the observed versus simulated data fits the 1:1 line. NSE ranges between $-\infty$ and 1. The percentage bias (PBIAS) is the simplest goodness-fit

Table 2. Criteria for evaluating the performance of HEC-HMS model.

\begin{tabular}{llll}
\hline Performance & \multicolumn{4}{l}{ Statistical Indicators } \\
\cline { 2 - 4 } Classification & $\mathrm{R}^{2}$ & NSE & PBIAS \\
\hline Very Good & 0.85 to 1.00 & 0.75 to 1.00 & PBIAS $< \pm 10$ \\
Good & 0.70 to 0.85 & 0.65 to 0.75 & $\pm 10 \leq$ to $< \pm 15$ \\
Satisfactory & 0.60 to 0.70 & 0.50 to 0.65 & $\pm 15 \leq$ to $< \pm 20$ \\
Acceptable & 0.40 to 0.60 & 0.40 to 0.50 & $\pm 20 \leq$ to $< \pm 25$ \\
Unsatisfactory & $\mathrm{R}^{2} \leq 0.40$ & NSE $\leq 0.40$ & PBIAS $\geq \pm 25$ \\
\hline
\end{tabular}


criterion, which measures the average tendency of the simulated values to be larger or smaller than their observed ones [40]. The optimal value of PBIAS is 0.0 , with low magnitude values indicating an accurate model simulation. Positive values indicate under-estimation bias, and negative values indicate over-estimation bias [41].

$R^{2}=\left[\frac{\sum_{i=1}^{N}\left(Q_{s i}-\overline{Q_{s}}\right)\left(Q_{o i}-\overline{Q_{o}}\right)}{\sqrt{\sum_{i=1}^{N}\left(Q_{s i}-\overline{Q_{s}}\right)^{2}} \sqrt{\sum_{i=1}^{N}\left(Q_{o i}-\overline{Q_{o}}\right)^{2}}}\right]$

$N S E=1-\frac{\sum_{i=1}^{N}\left(Q_{s i}-Q_{o i}\right)^{2}}{\sum_{i=1}^{N}\left(Q_{o i}-\overline{Q_{o}}\right)^{2}}$

PBIAS $=\left[\frac{\left(Q_{o i}-Q_{s i}\right)}{\sum_{i=1}^{N}\left(Q_{o i}\right)}\right] \times 100$

where $N$ is the total number of data points; $Q_{s}$ is the simulated runoff; $Q_{o}$ is the observed runoff; $\overline{Q_{s}}$ and $\bar{Q}_{o}$ are the average of simulated and observed runoff, respectively. All runoff units are cms.

General criteria and corresponding classification for evaluating the performance of the hydrological model was developed based on $\mathrm{R}^{2}$, NSE and PBIAS performance ratings as presented in Table 2.

\section{Model application at creek catchment scale}

The flow simulation of each creek catchment was done using calibrated parameters on daily basis for the same period. For this purpose, the delineation of creek catchments was done in ArcGIS 10.1. Total 15 sub-catchments outlets (5-19) were delineated as shown in Fig. 6. In Meinong creek catchment the model is simulated at four locations as represented by number 5 to 8 and model verification is performed by comparing with the ratio of maximum design discharge and simulated average runoff.

\section{Results and discussion}

\subsection{Spatio-temporal rainfall distribution}

Keeping in view the spatiotemporal rainfall variabilities of Taiwan, the study area rainfall analysis was performed. The three-year (2016-2018) hourly rainfall distribution of fifteen rain gauge stations is shown in Fig. 7. It was observed that the maximum intensity rainfall spell is during the summer monsoon season and distribution is under heavy to extremely heavy rainfall. The mountainside rain gauge stations in Meinong and Qishan districts showed extremely heavy rainfall while the planeside stations have heavy rainfall characteristics.

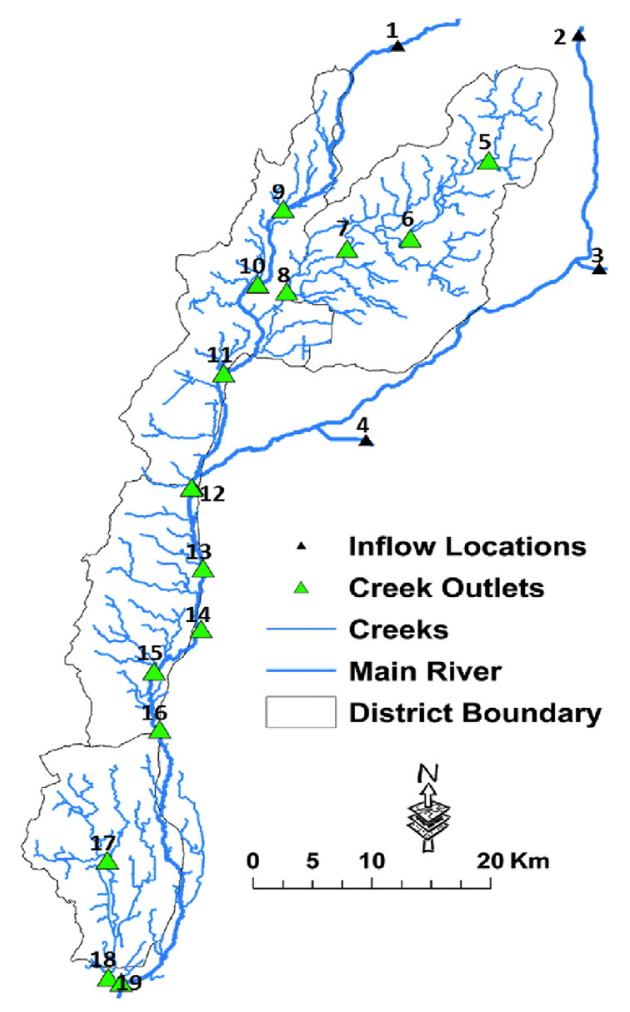

Fig. 6. Creek catchments and number of outlets in the study area.

The hyetograph distributions indicated that 2017 rainfall spells are less and low in magnitude rather than 2016 and 2018. The high intensity rainfall spell from 23 to 26 August 2018 was observed due to lowpressure system that brought torrential rain and flooding in southern Taiwan. The distribution of maximum hourly rainfall and maximum daily rainfall occurred on 23 August 2018 is shown in Fig. 8 . This selected rainfall spell is maximum during the three years and all the stations have $60 \mathrm{~mm} \mathrm{~h}^{-1}$ rainfall indicating extreme conditions. This spell created flash flooding in urban areas and CWB announced a warning for extremely torrential rain (500 $\mathrm{mm}$ or more in $24 \mathrm{~h}$ ) as the storm loomed.

The spatial distribution of hourly rainfall observed on 23 August 2018 during time 11:00 to 14:00 is shown in Fig. 9. This selected time is the centre of heavy rainfall spell and indicated the occurrence of torrential rain due to low pressure development near the coast and low areas. The spell moves toward mountainsides and create extremely heavy rainfall and flash flood due to terrain, local winds and orographic effects. The spatial distribution of rainfall with time is important for rainfall-runoff process and environmental management system such as agriculture, municipal as well as industrial water requirements. The spatio-temporal analysis provides information about local rainfall 


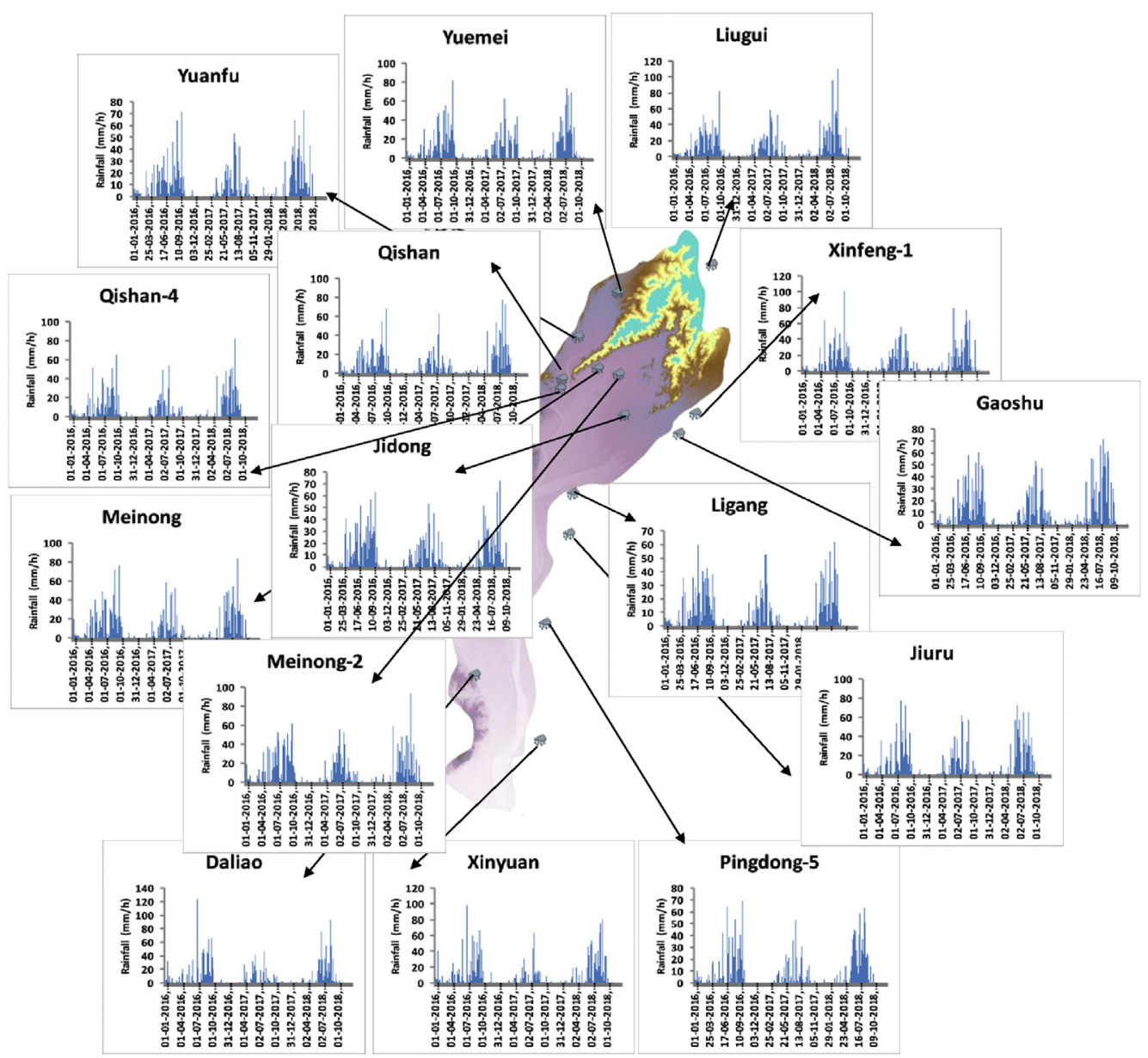

Fig. 7. The comparison of temporal rainfall intensity from 2016 to 2018.
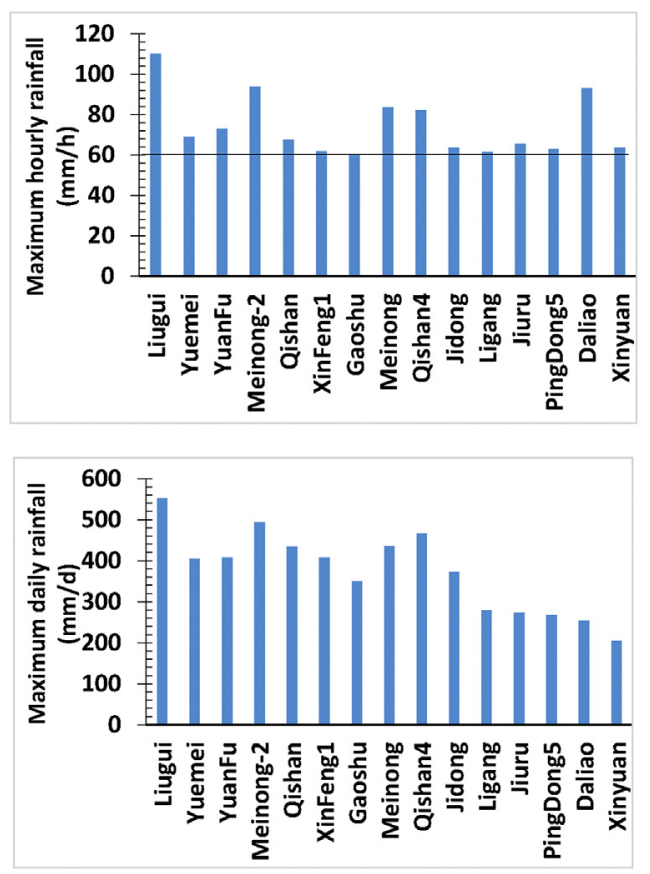

Fig. 8. Comparison of maximum hourly and daily rainfall of all rain gauge stations. distribution characteristics to simulate the runoff in ungauged catchments using physically based semidistributed continuous hydrological model.

\subsection{Hydrological model simulation and performance based on physical parameters}

The model simulation on daily time scale was performed using initial model setup and original parameters quantified from measurable physical catchment attributes (such as topography, landuse and slope) as shown in Fig. 10. The obvious correspondence of simulated and observed flows $\left(R^{2}=\right.$ 0.623 and NSE $=0.576$ ) of this simulation before model calibration indicated that the performance of model is acceptable and satisfactory based on the criteria in Table 2. This performance also indicated that the quantified physical parameters from DEM, soil and land use are reliable and can be used further for HEC-HMS model calibration and validation. Moreover, the selected loss (Soil Conservation Service Curve Number (SCS-CN)), transform 

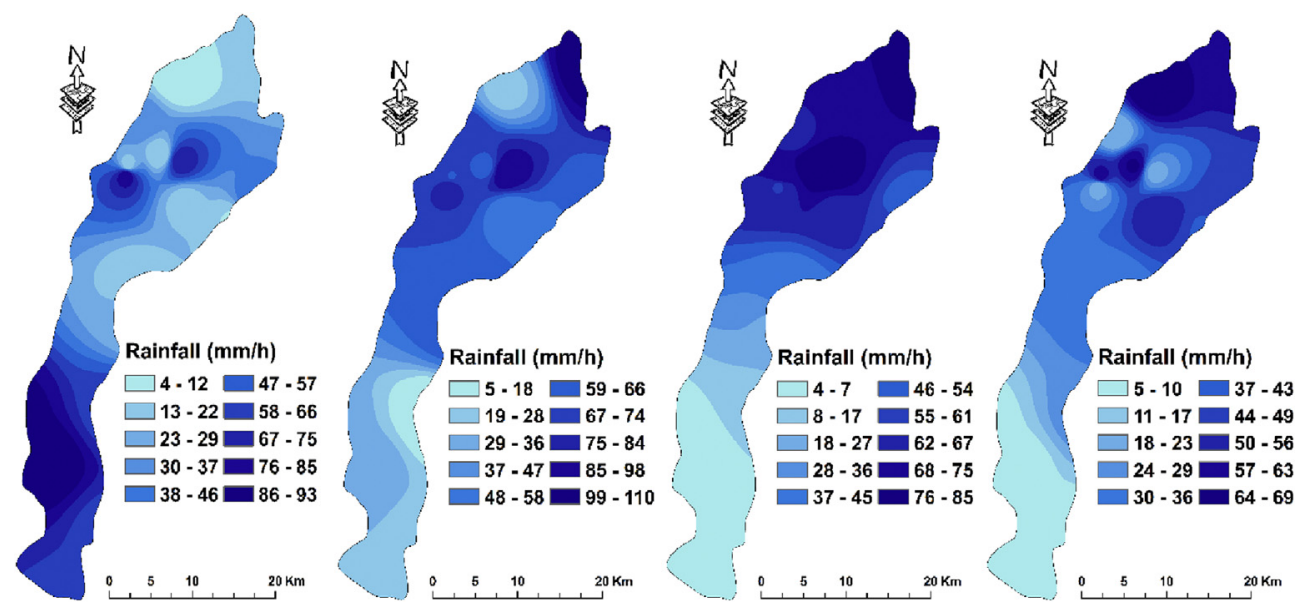

Fig. 9. Spatial variation of rainfall spell observed on 23 August 2018 during time 11:00 to 14:00.

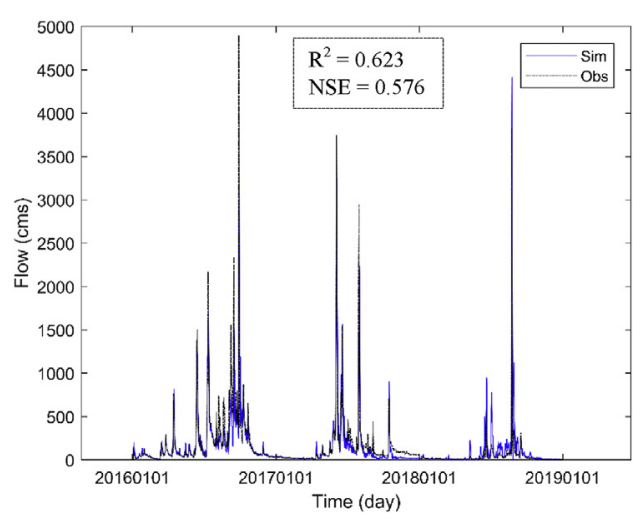

Fig. 10. HEC-HMS model simulation and performance on daily time scale before calibration at Li-Ling Bridge (No. 12 in Fig. 6).
(Soil Conservation Service Unit Hydrograph (SCS$\mathrm{UH})$ ) and flow routing (Muskingum) methods in HEC-HMS are suitable for rainfall-runoff process of study area. [42]; study also support the rainfallrunoff simulation results based on catchment physical characteristics such as topographic, soil and land use.

\subsection{Calibration and validation of hydrological model}

The direct runoff at the gauged location was calibrated on hourly time scale from 2016 to 2017. Only two parameters (CN and Ia) were used in optimization trials in HEC-HMS model, while other parameters were kept same and the most accurate

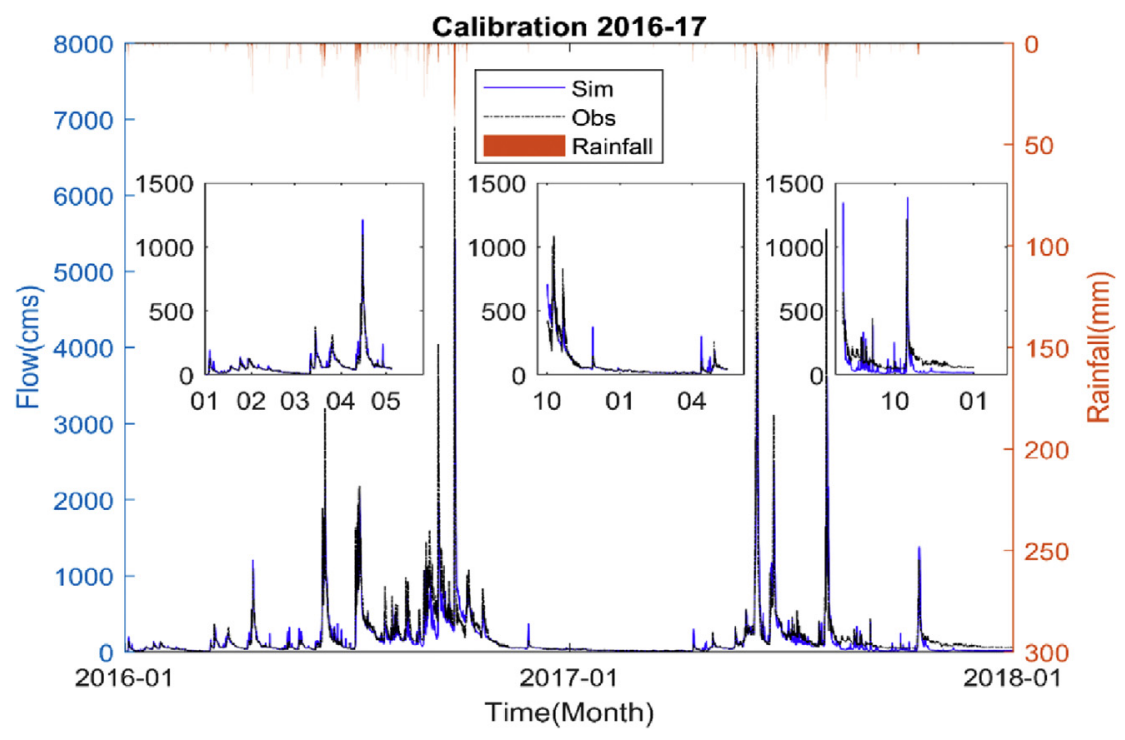

Fig. 11. Comparison of simulated and observed hydrographs during calibration. 


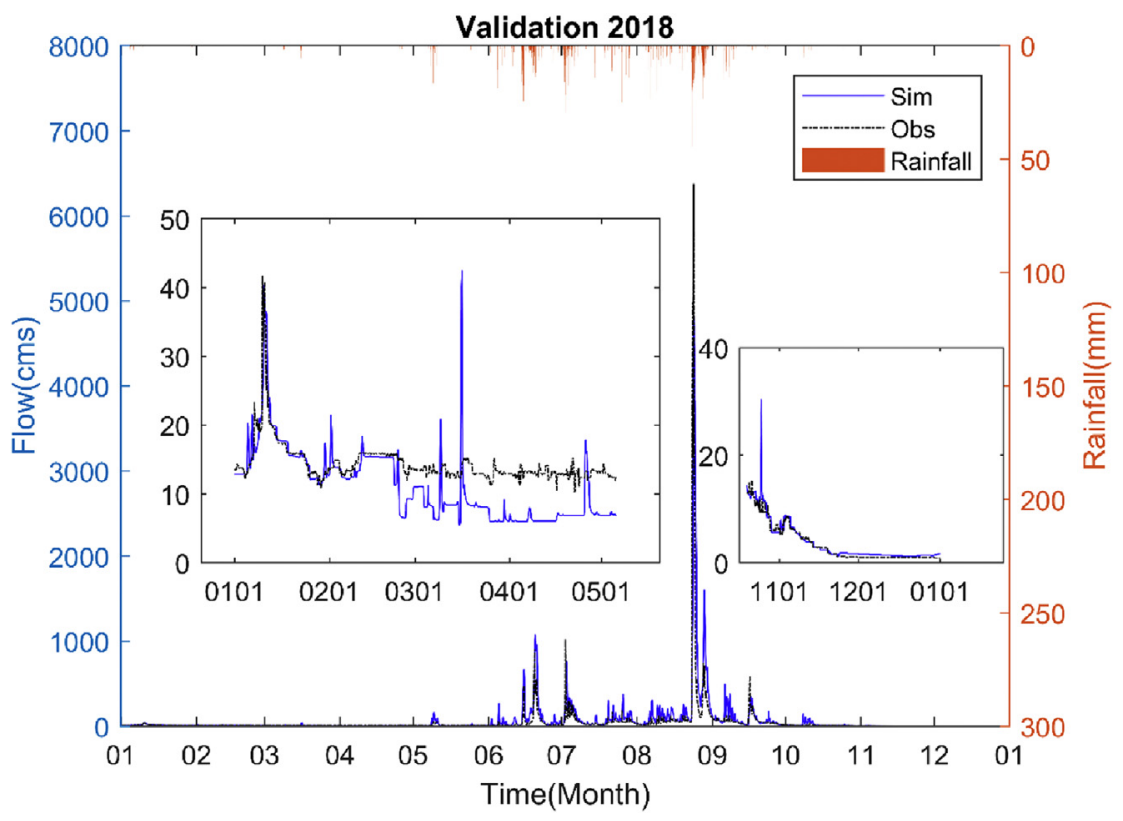

Fig. 12. Comparison of simulated and observed hydrographs during validation.

optimized values were eventually generated and used. The simplex optimization method with peakweighted RMS objective function was used to evaluate the $\mathrm{CN}$ and Ia parameters, simultaneously. The auto-calibration using optimization method helped to calibrate the parameters. The optimization was performed by selecting the maximum and minimum value range for the parameter to be modified. The $\mathrm{CN}$ value was modified using scale factor between the range $(0.5-1.25)$ and 0.716 optimum value was found. Similarly, the initial abstraction (Ia) was optimized using scale factor between the range $0.5-1.05$ with optimum value 0.986 . The optimum or calibrated $\mathrm{CN}$ and Ia values were achieved by changing the default values between \pm 0.75 and \pm 0.55 , respectively. The comparison between observed and calibrated hydrographs are shown in
Fig. 11 by changing $\mathrm{CN}$ and Ia. The comparison indicated that the model did not predict the streamflow well for high peaks (underestimated) while the hydrograph shape and timing of peaks matched well. However, concerning the low flows during dry season, the results of the hydrological model showed a reasonable fit between the model and observations after optimization, although the model tended to overestimate the runoff peak. Similarly, the validated hydrograph shape is matching well with observed data but also underestimate the peak flow during the wet season of year 2018 as shown in Fig. 12.

The underestimation of high flows during wet season may be due to unregulated observations data or the flow increased moderately at the beginning of the wet season due to early arrival of rain in May
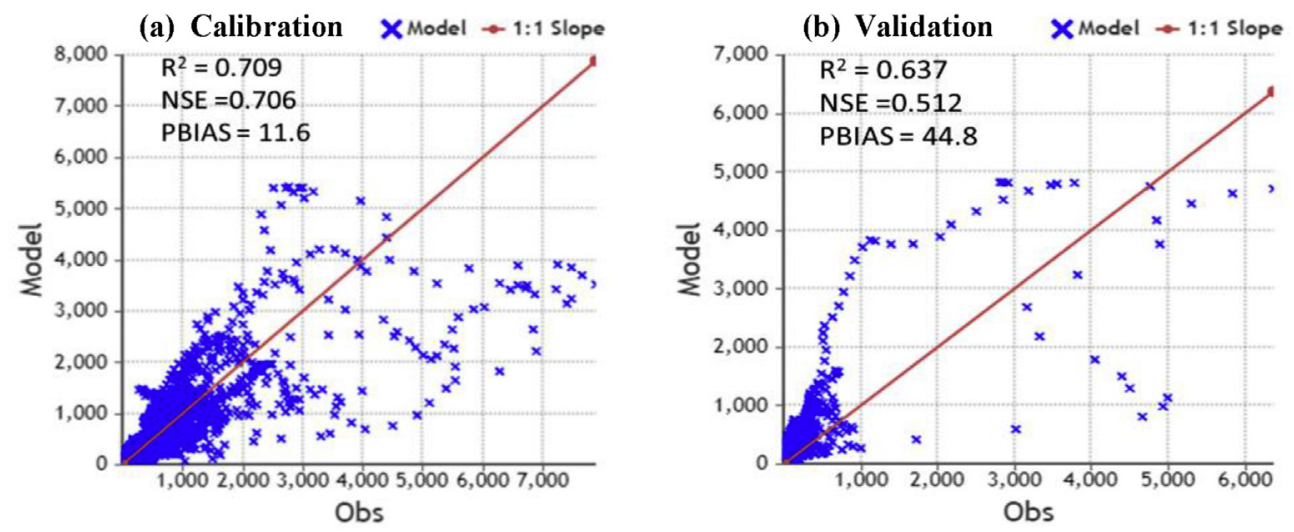

Fig. 13. Regression between simulated and observed flow during calibration and validation. 

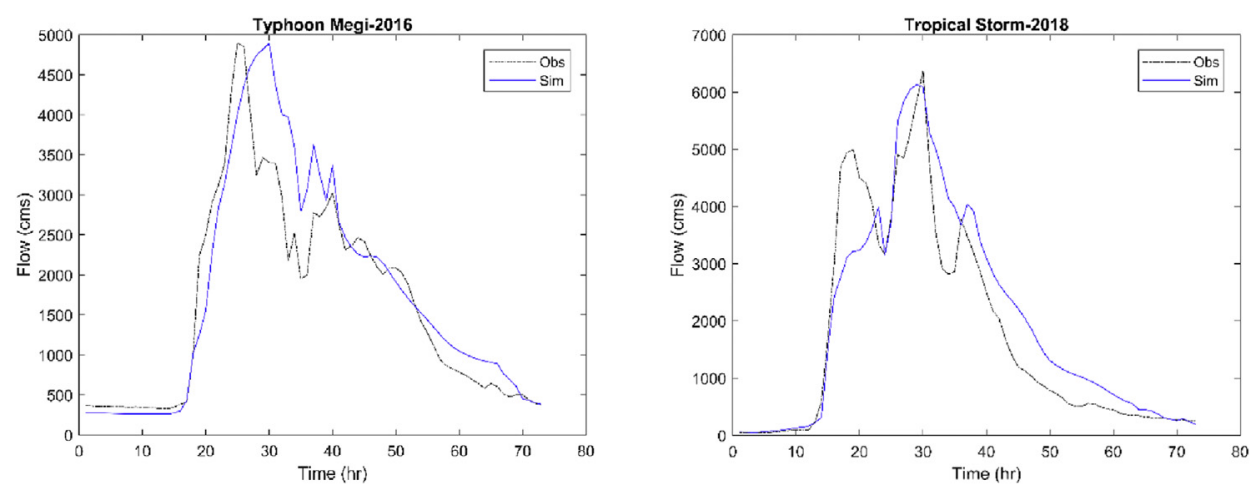

Fig. 14. Event base HEC-HMS simulation for Typhoon Megi-2016 and Tropical Storm-2018

and June. While the overestimation during dry season may be due to different diversions such as water diversion toward irrigation channels for downstream farming or storage maintenance in reservoir for water supply, which may be not accounted by model.

The model evaluation was performed for the calibration and validation period using hourly time simulation. The three statistical evaluation criteria with values of NSE $=0.706, \mathrm{R}^{2}=0.709$ and, PBIAS $=$ $11.6 \%$ showed good simulation between the estimated and observed values for the calibration period as shown in Fig. 13a. While the relative less values of these criteria for the validation period (2018) indicated that model is reasonably well (acceptable) in terms of $R^{2}$ and NSE and can be applied to simulate the flows for creek catchments. The regression between simulated and observed flows during calibration and validation time on hourly basis is shown in Fig. 13. The plotted points above the line 1:1 represent an overestimation, while those below that indicate an underestimation. The peak flow points of simulated are under the line 1:1 represent the underestimation of model while low flow points are plotted above line indicating

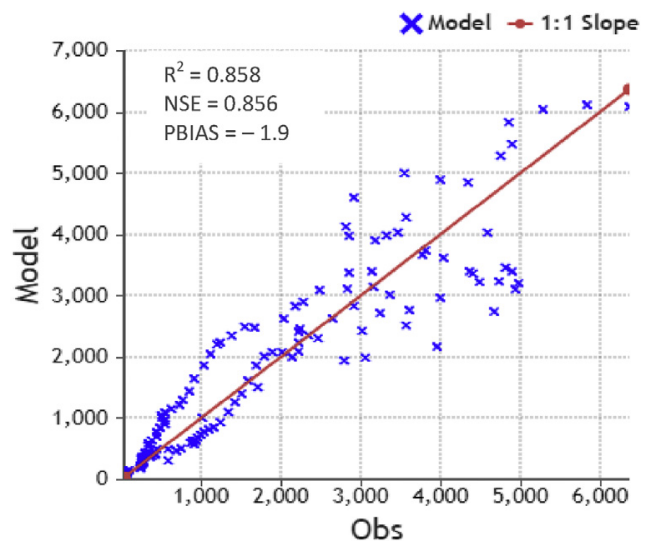

Fig. 15. Model performance and regression between simulated and observed flows of both selected rainfall events. overestimation. The model evaluation is unsatisfactory for validation based on PBIAS. The model was unable to compute high flow peaks, where the flow may be increased moderately at the beginning of the wet season due to early arrival of rain in May and June. The statistical evaluation indicator (PBIAS) is very sensitive to minor difference between peak values of flow. It looks that model simulation on daily basis is better than hourly basis with keeping same parameters.

\subsection{Event base hydrological model simulation and performance}

The calibration and validation of model was performed using continuous base modeling for 2016-2017 and 2018, respectively. It was obtained that the model simulation for validation period was unsatisfactory based on PBIAS. Hence keeping in view, the model simulation is performed using event base data for the evaluation. For this purpose, two rainfall events were selected (Typhoon Megi2016 and low pressure Tropical Storm 2018). The simulation is performed using same calibration parameters on hourly time step as shown in Fig. 14 . Typhoo Megi-2016 simulation is done for three days (September 27 to 29) and it was analyzed that the model simulated the flows well but there is a difference in the peak time by five hours between observed and simulated hydrographs. Similarly, the Tropical Storm-2018 simulation is done for three days (August 24 to 26) and it was observed that the hydrograph time to peak and flow peak matched well.

The model performance evaluation was also carried out using the criteria of Table 2 as shown in Fig. 15. The values of statistical indicators for both events indicated that the performance of the model is very good based on event base simulation rather than continuous simulation. Very good performance of the model also satisfied the selection of parameters 

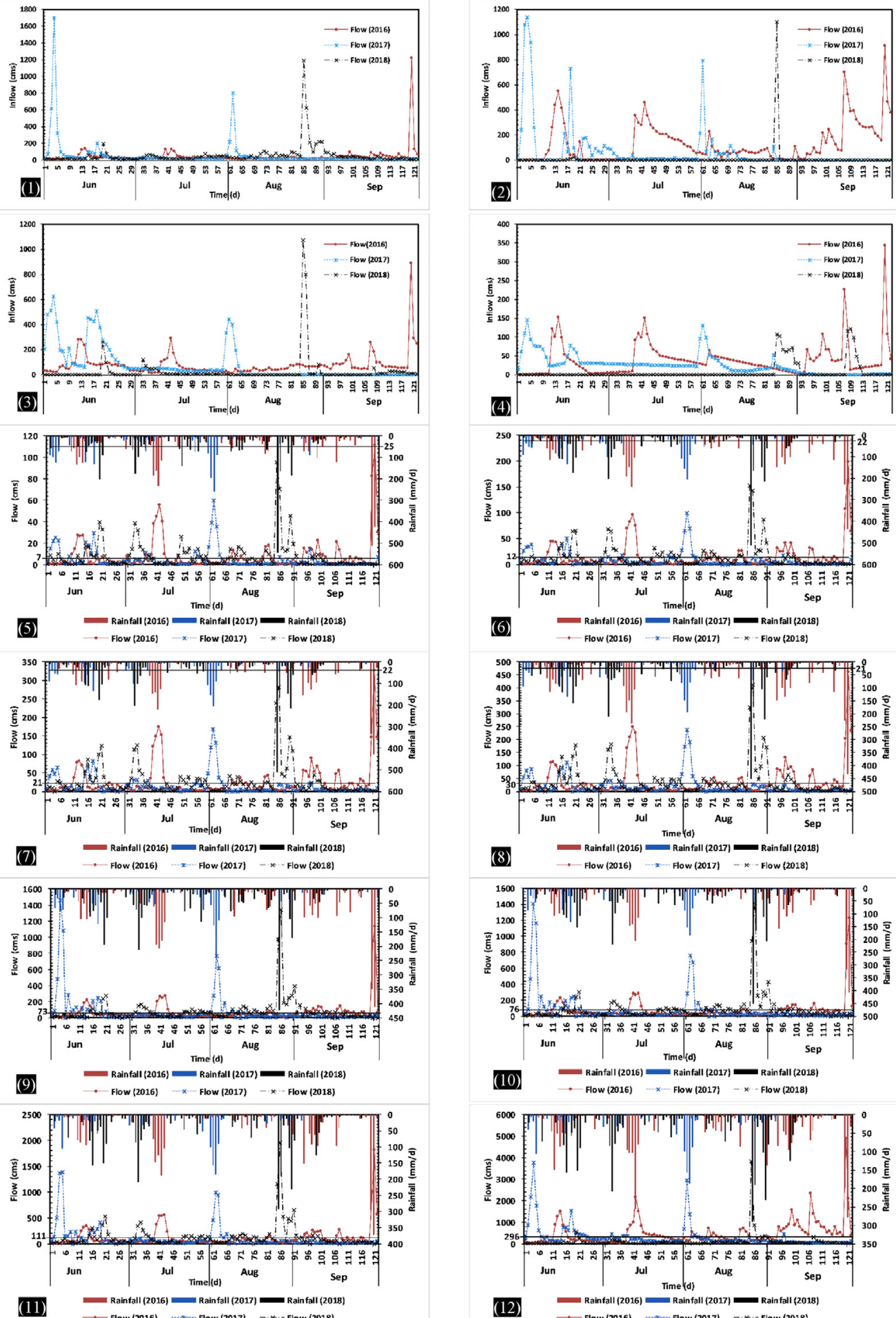

Fig. 16 The simulated flow using the calibrated parameter (CN and Ia) in creek catchments from upstream to downstream according to catchment outlets. 


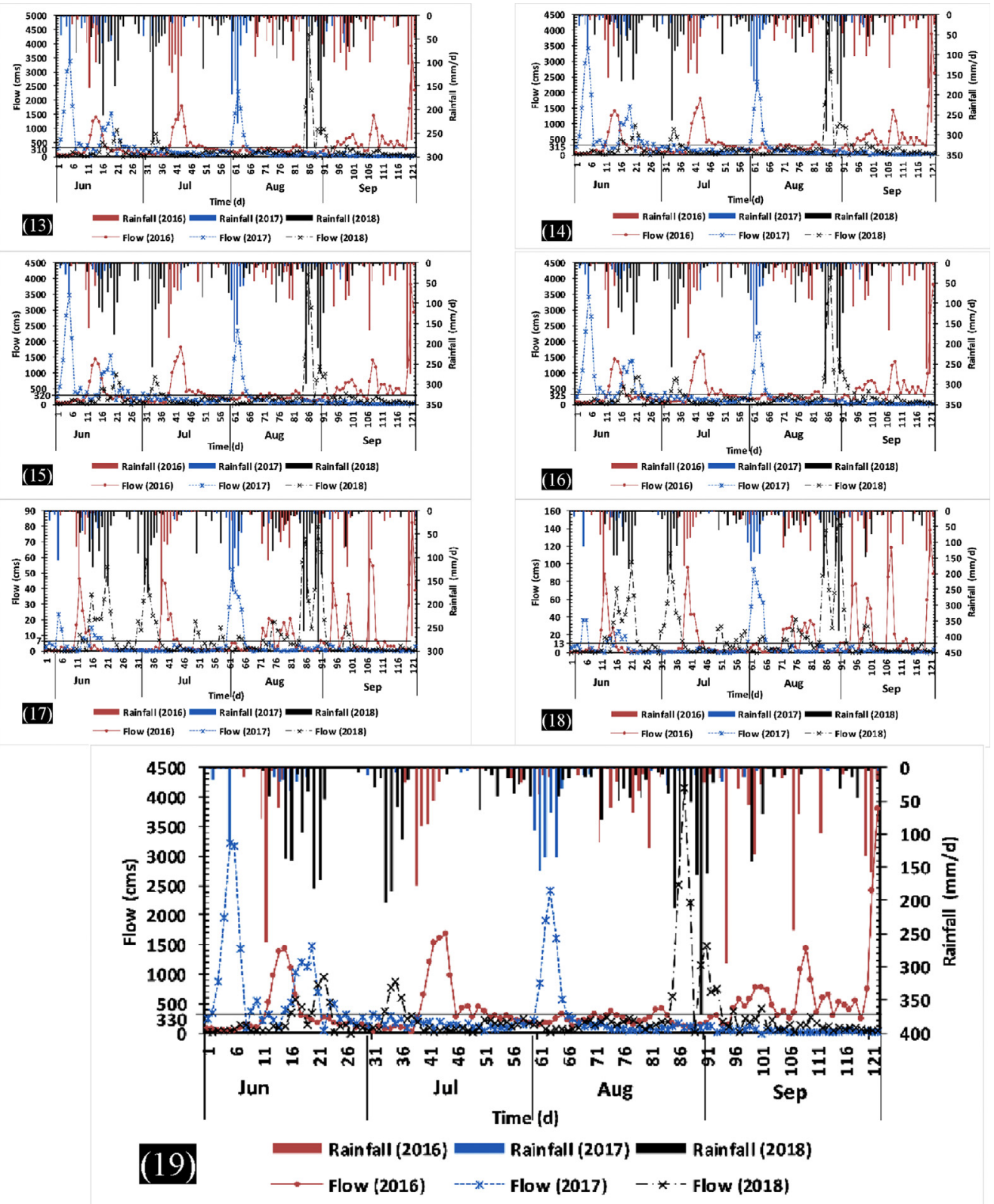

Fig. 16. (continued).

for calibration that can be used to simulates the runoff of creek catchments.

\subsection{Simulating runoff of creek catchments using calibrated parameters}

The rainfall-runoff simulation of creek catchments was done using estimated physical parameters. The model simulates the flow on hourly basis and then converted into daily flows. It was analyzed that the continuous hydrological model simulate the wet and dry season flow reasonably well and successfully synthesizes the hydrological processes during wet and dry season. The simulated flow hydrographs of each creek catchment according to the numbering of catchments outlets in Fig. 6 are shown in Fig. 16. The hydrographs shape and peak time with respect to rainfall duration and amount indicated that model reasonably simulates the flows in ungauged catchments such as Meinong. In addition, 
the recession part in low flow hydrographs represents the catchment hydrology and its natural response to rainfall. After simulation and analysis, the wet season flows during monsoon period (June to September) were separated as shown in Fig. 16. The hydrographs features indicated that calibrated model is reasonable to simulate the flows in ungauged catchments. The influence of inflow hydrographs can be seen in the downstream catchments. The runoff simulation during 2018 is relatively dry than 2016 and 2017. Only a single storm occurred in late August 2018 that created high runoff flow in all catchments. Similarly, in analyzing a flood event, the most important aspect of the hydrograph is the peak flow, because the peak flow corresponds to the maximum downstream flooding that can be visualized clearly in Fig. 16. In contrast, peaks that are significantly less than the maximum may correspond to increased water levels, but not necessarily a flood event. The model verification was performed with the analysis of simulated runoff in MCC.

\subsection{Analysis of Meinong creek catchment (MCC) and model verification}

The flow analysis of MCC has been performed to verify the model parameters. The MCC is considered ungauged because of unavailability of any flow measuring system. Therefore, the model verification is performed on that catchment to analyze the capability of physically based semi-distribution continuous hydrological model. The MCC area is located on the upper reaches of the Kaoping delta's alluvial fan with hills surrounding the west, north, and east sides. This is the region where the Kaoping river flows directly through the Central Taiwan Mountain Range, into plains, and starts its sedimentation process. Because gravel and sand are deposited first and comprise a porous soil structure, it is an important recharge area for groundwater in the delta. The urbanized area is at the central plains area with an elevation of about $45 \mathrm{~m}$ through which the Meinong creek flows from the northeast to the southwest and into the Kaoping river. The total irrigated area is 4858 ha, including Jhongtan, Jiyang and Jhuzimen (Fig. 17). The maximum designed discharge is $770 \mathrm{cms}$ at the San-Chia-Shui area and $980 \mathrm{cms}$ at the confluence with the Qishan creek [29]. The current dike system ends at about Fuan village, because the downtown of Meinong is too dense to build a dike. In addition, because the slope of the terrain around the confluence of the Qishan creek and Meinong creek is quite gradual, water easily congests and flows back if the Qishan creek is simultaneously in a high water level. The San-ChiaShui area is a flood-prone area when the congestion of water elevates the water level. The main creek consists of three major tributaries: the Shuang creek, the Chiangziliou creek, and the Youzilin creek. These tributaries gather the over-land flow from the hills on the three sides and converge at San-ChiaShui. The creek makes a U-turn to bypass some higher ground and then directly flows through Fuan village, Jhongtan, Dexing and Chingshui villages after flowing through the downtown area (Fig. 17). After infiltration, the remaining water continuously flows into the mainstream of the Kaoping river through the bottom part of the triangle, where the larger space functions as a floodplain. This catchment triangle illustrates an original mechanism of the water system: a huge amount of storm water is collected in the upper area of the triangle and then either flows together into the Kaoping river or floods into the bottom of the triangle. This system provides the midstream of the Meinong creek with a livable and safer waterfront than the downstream area.

The Meinong district flood condition in the different year was analyzed using literature data from Water Resources Agency. It was observed that there is a flooding condition almost every year after Typhoon Mindulle in 2004 due to the increased frequency of extreme rainfall. The Typhoon Mindulle flooded an area of 108 ha with the maximum inundation depth of $1.5 \mathrm{~m}$. Typhoon Wutip in 2007 had created serious flooding in downtown Meinong and more than 4200 residents were in danger. Typhoon Kalmaegi in 2008 flooded an area of 250 ha. Typhoon Morkot in 2009 inundated an area of 150 ha; Typhoon Fanapi in 2010 had flooded an area of 120 ha. Typhoon Talim in 2012 created flooding in whole Kaohsiung and Pingtung County while the agricultural loss was more than 700 million NTD. Typhoon Megi in 2016 with $83 \mathrm{~mm} \mathrm{~h}^{-1}$ rainfall intensity inundated about 130 ha area while the flooding depth was about $0.3-0.5 \mathrm{~m}$. Tropical Storm-2018 due to low-pressure monsoonal rainfall created pluvial flooding with maximum flooding depth more than $1 \mathrm{~m} \mathrm{ha}^{-1}$. The inundation area was 17.2 ha. The review of flooding and historical 


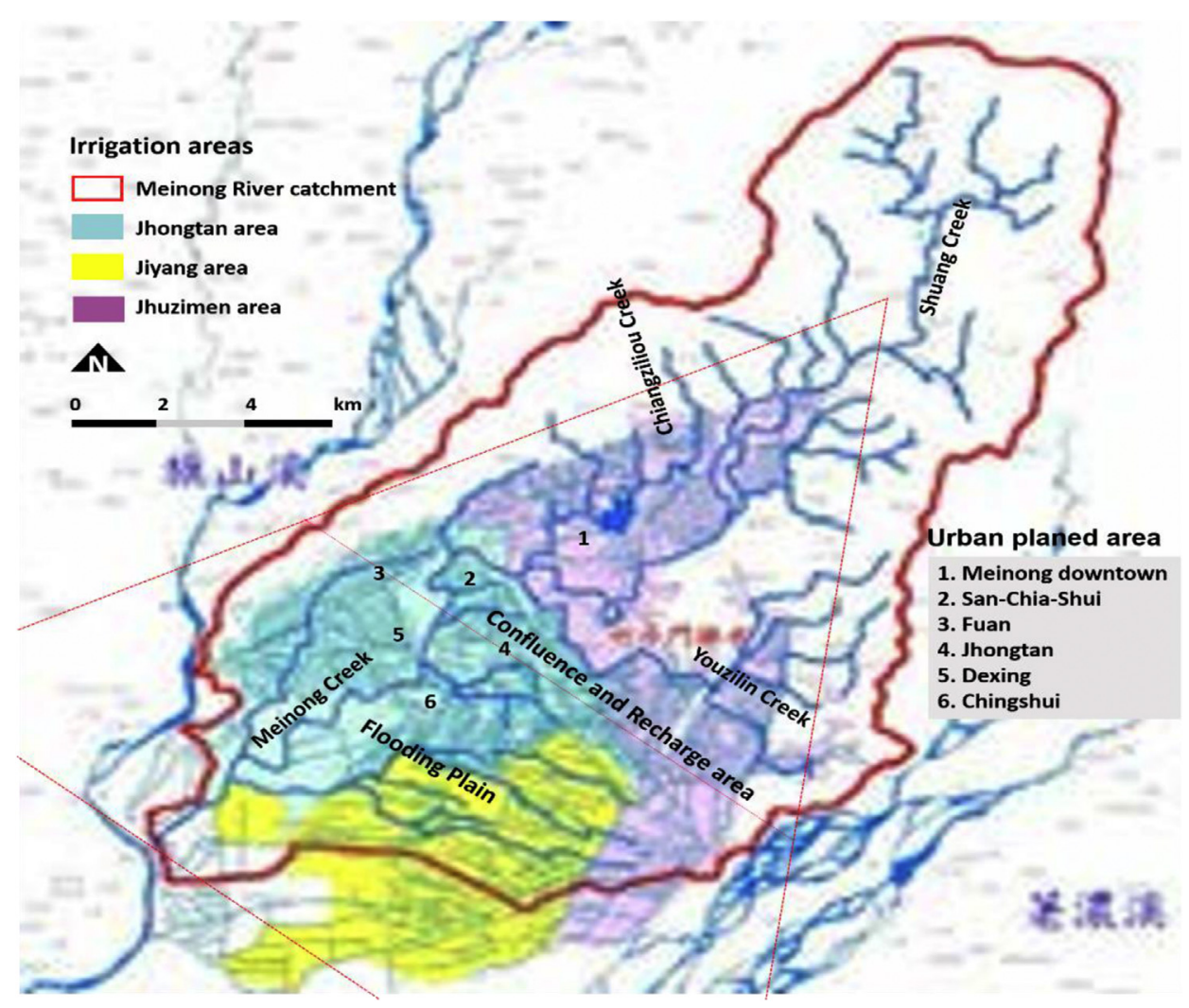

Fig. 17. The location of villages, the water texture and irrigation network of Meinong creek catchment area (Source: Based on [43] and [29]; Map by author).

flooding area maps illustrated that the main locations of floods are concentrated on the plain at the mountain (Fig. 18). The flow rate slows down in the plains, which results in water congestion and flooding. The San-Jia-Shui area is relatively lowlying land where storm water easily accumulates.

Based on the flooding history and ungauged situation of Meinong creek catchment (MCC), the flow simulation has been performed for better management of water system and future application of the model for flood prediction. The simulation results indicated that most of the river water comes from rainfall, and it was observed that there is a significant difference in flow rate between summer (rainy) and winter (dry) seasons. The model simulation results were compared with maximum design flows at upstream to downstream locations in MCC. The ratio of maximum design flow between outlets 6 and 7 is 0.57 while the simulated average flow also presented the same ratio at same locations. This comparison indicated that HEC-HMS model has a capability of runoff simulation in ungagged creek catchments using physical parameters and can be adopted for future flood and dry flows prediction in creek catchments of Kaohsiung area Taiwan.

The simulated rainfall-runoff hydrographs at three outlets in MCC indicated that the peak flows correspond to the maximum rainfall occurrence, also the hydrograph shape and timing of peaks matched well. The application of calibrated parameters with estimated other physical parameters in hydrological modeling reasonably produced the runoff hydrographs. The monsoon four months (Jun to Sep) rainfall-runoff hydrographs in Fig. 19 indicates that the monsoon rainfall produce, $12 \mathrm{cms}$ average runoff at outlet 6 in San-Chia-Shui upstream area while at outlet 7 the average runoff become $21 \mathrm{cms}$. At the outlet of MCC (the confluence with the Qishan creek) the monsoon rainfall produced $30 \mathrm{cms}$ average runoff. The estimated runoff potential can be used to manage the water system in Meinong area during monsoon season. This shows that HEC-HMS is suitable for the studied catchments. From the results, we can conclude that the complexity of the model structure does not determine its suitability and efficiency. Though the 

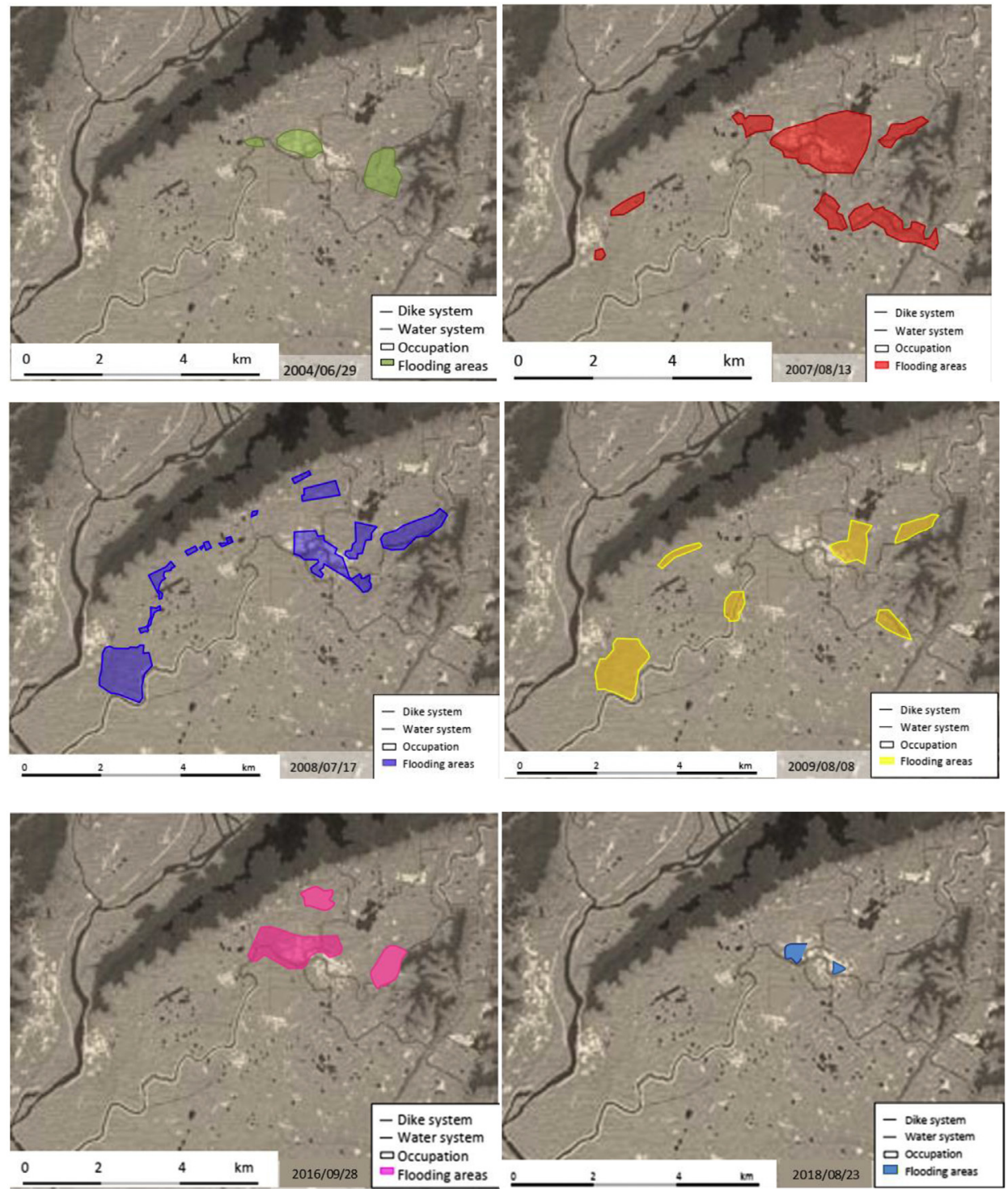

Fig. 18. The distribution of flooding area of historical typhoons in Meinong (Source: Based on [44]; Map by author).
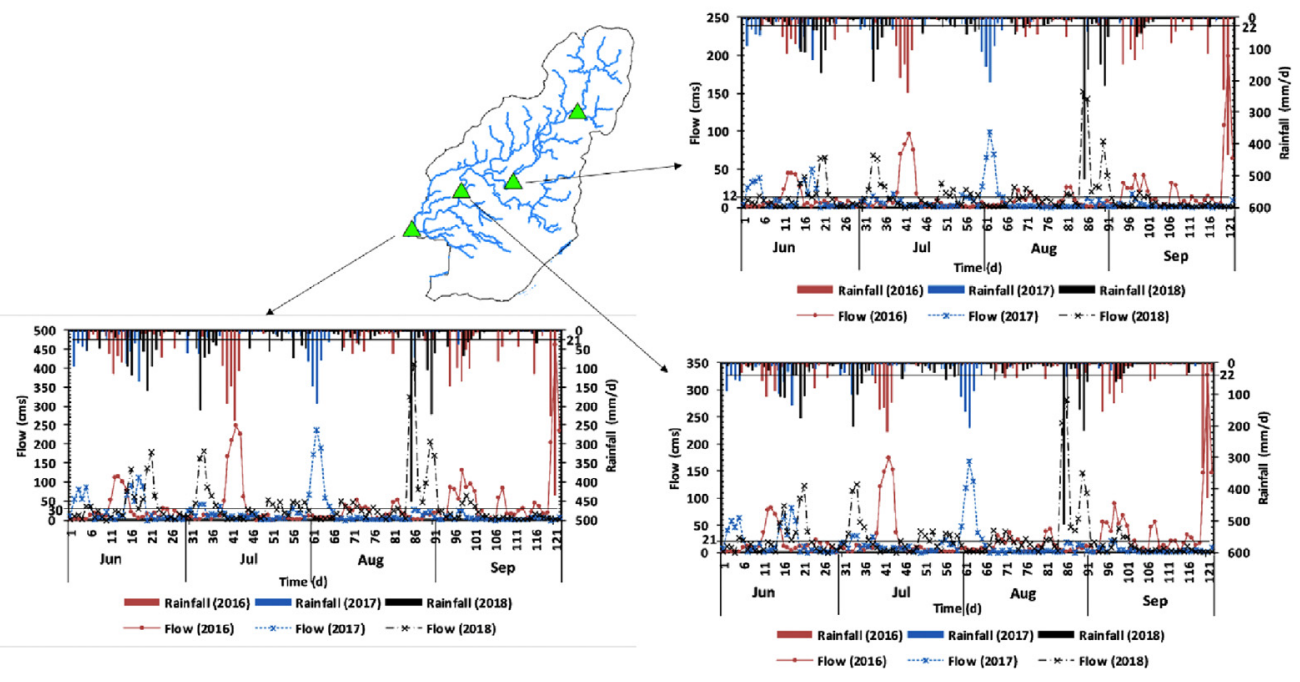

Fig. 19. Rainfall-runoff simulated hydrographs in Meinong creek catchment. 
structure of HEC-HMS is simple, it is a powerful tool for flood forecasting. A further application of HEC-HMS should be encouraged to confirm its suitability for the Taiwan catchments.

\section{Conclusion}

This study demonstrated that the physically based semi-distributed hydrological (HEC-HMS) model is suitable and adaptable to simulate rainfall-runoff flows on event as well as continuous time scale with calibration and validation in Kaohsiung area Taiwan. The model is fully based on the hydrological characteristics, topography, soil type, and land use of the study area. Overall, the HEC-HMS model performance was satisfactory in terms of Nash Sutcliffe Efficiency (NSE) and coefficient of determination $\left(R^{2}\right)$ based on the selected loss, transform and flow routing methods. The modeling results indicated the significant difference between dry and wet seasons and water availability in the main river and creeks is mainly due to monsoonal rainfall that brings peak flows and pluvial flooding. The same model was applied using calibrated parameters (CN and Ia) in Meinong creek catchment where there is no hydrological gauged station with sparse meteorological stations. The comparative results between maximum design flow and average simulated monsoonal flows verified the application of physically based semidistributed HEC-HMS model. Understanding water availability from Meinong creek catchment will be useful to water resources managers, especially in irrigation, domestic and industry water use sectors. Therefore, it is concluded and suggested that the methodologies developed in this research can also be applied in other ungauged catchments and regions with similar characteristics for hydrology and water resources assessment. The developed model in the study catchment can be applied to generate more detailed information for modeling work, for water resource management and planning purposes under future climate scenarios. The outputs of this study will help hydrologists to understand the efficiency and application of physically based semi-distributed hydrologic model in river flow (rainfall-runoff) modeling.

\section{Acknowledgements}

This research is conducted with the financial support of Ministry of Science and Technology, Taiwan under Grant no. MOST-108-3114-M-008001-. The authors highly acknowledge the authorities and agencies for the provision of valuable data such as National Land Surveying and Mapping
Center, Ministry of Interior, Taiwan (NLSC); Central Geological Survey (CGS), MOEA; Water Resource Agency (WRA); Council of Agriculture (COA).

\section{References}

[1] Water Resources Agency. Hydrological year book. Taipei, Taiwan: Water Resources Agency (WRA); 2017 (In Chinese).

[2] Water Resources Agency. The third stage management project of climate change impacts and adaptation on water environment (3/5). Taipei, Taiwan: Water Resources Agency; 2016. 2016. (In Chinese).

[3] Chu X, Steinman A. Event and continuous hydrologic modeling with HEC-HMS. J Irrig Drain Eng 2009;135: 119-24.

[4] Beven K. On subsurface stormflow: Predictions with simple kinematic theory for saturated and unsaturated flows. Water Res Res 1982;18:1627-33.

[5] Vassova D. Comparison of rainfall-runoff models for design discharge assessment in a small ungauged catchment. Soil Water Res 2013;8:26-33.

[6] Scharffenberg W, Ely P, Daly S, Fleming M, Pak J. Hydrologic modeling system (HEC-HMS): Physically-based simulation components. In: 2nd joint federal interagency conference, Las Vegas, NV, June 27 - july 1, 2010; 2010.

[7] Ibrahim-Bathis K, Ahmed SA. Rainfall-runoff modelling of Doddahalla watershed-an application of HEC-HMS and SCN-CN in ungauged agricultural watershed. Arab J Geosci 2016;9:170-86.

[8] Sengupta A, Adams SK, Bledsoe BP, Stein ED, McCune KS, Mazor RD. Tools for managing hydrologic alteration on a regional scale: Estimating changes in flow characteristics at ungauged sites. Freshw Biol 2018;63:769-85.

[9] He Y, Bardossy A, Zehe E. A review of regionalisation for continuous streamflow simulation. Hydrol Earth Syst Sci 2011;15:3539-53.

[10] Wale A, Rientjes T, Gieske A, Getachew H. Ungauged catchment contributions to Lake Tana's water balance. Hydrol Process 2009;23(26):3682-93.

[11] Chea S, Oeurng C. Flow simulation in an ungauged catchment of Tonle Sap Lake basin in Cambodia: Application of the HEC-HMS model. Water Utility J 2017;17:3-17.

[12] Meresa $\mathrm{H}$. Modelling of river flow in ungauged catchment using remote sensing data: Application of the empirical (SCS-CN), artifcial neural network (ANN) and hydrological model (HEC-HMS). Model Earth Sys Environ 2019;5:257-73. https://doi.org/10.1007/s40808-018-0532-z.

[13] Feldman AD. Hydrologic modeling system HEC-HMS, technical reference manual. Davis, CA, USA: U.S. Army Corps of Engineers, Hydrologic Engineering Center, HEC; 2000.

[14] Halwatura D, Najim MMM. Application of the HEC-HMS model for runoff simulation in a tropical catchment. Environ Model Software 2013;46:155-62.

[15] USACE. Hydrologic modeling system (HEC-HMS) applications guide: Version 3.1.0. Davis, CA: Institute for Water Resources, Hydrologic Engineering Center; 2008.

[16] Laaha G, Demuth S, Hisdal H, Kroll CN, van Lanen HAJ, Nester T, Rogger M, Sauquet E, Tallaksen LM, Woods RA, Young A. Prediction of low flows in ungauged basins in; runoff prediction in ungauged basins: Synthesis across processes, places and scales. In: Blöschl G, Sivapalan M, editors. Thorsten Wagener, Alberto Viglione and Hubert Savenije. Published by Cambridge University Press; 2013.

[17] Tassew BG, Belete MA, Miegel K. Application of HEC-HMS model for flow simulation in the Lake Tana basin: The case of Gilgel abay catchment, upper blue nile basin, Ethiopia. Hydrology 2019;6:21-38.

[18] Abbas T, Nabi G, Boota MW, Faisal M, Azam MI, Yaseen M, Hussain F. Continuous hydrologic modeling of major flood 
hydrographs using semi-distributed model. Sci Int 2015; 27(6):6231-7.

[19] Majidi A, Vagharfard H. Surface run-off simulation with two methods using HEC-HMS model (Case study: Abnama Watershed, Iran). Curr Adv Environ Sci 2013;1(1):7-11.

[20] Du J, Qian L, Rui H, Zuo T, Zheng D, Xu Y, Xu C-Y. Assessing the effects of urbanization on annual runoff and flood events using an integrated hydrological modeling system for Qinhuai River basin, China. J Hydrol 2012;464: 127-39.

[21] Al-Abed N, Abdulla F, Khyarah AA. GIS-hydrological models for managing water resources in the Zarqa River basin. Environ Geol 2005;47:405-11.

[22] Yusop Z, Chan C, Katimon A. Runoff characteristics and application of HEC-HMS for modelling stormflow hydrograph in an oil palm catchment. Water Sci Technol 2007;56: 41-8.

[23] Shih D-S, Chen C-J, Li M-H, Jang C-S, Chang C-M, Liao Y-Y. Statistical and numerical assessments of groundwater resource subject to excessive pumping: Case study in southwest Taiwan. Water 2019;11(2):360. https://doi.org/ 10.3390/w11020360.

[24] Wu R-S, Shih D-S. Modeling hydrological impacts of groundwater level in the context of climate and land cover change. Terr Atmos Ocean Sci 2018;29:341-53.

[25] Young C-C, Liu W-C, Wu M-C. A physically based and machine learning hybrid approach for accurate rainfallrunoff modeling during extreme typhoon events. Appl Soft Comput 2017;53:205-16.

[26] Young C-C, Liu W-C. Prediction and modelling of rainfall-runoff during typhoon events using a physicallybased and artificial neural network hybrid model. Hydrol Sci J 2015;60(12):2102-16.

[27] Taiwan Government Report (TGR). Hydrological year book of taiwan. Ministry of Economic Affairs: Water Resources Agency; 2011a (In Chinese).

[28] Taiwan Government Report. The second investigation of Kao-Ping River. Taiwan: Water Resources Agency; 2011b (In Chinese).

[29] Taiwan Government Report (TGR). Taiwan water resources agency. Report on the regulation planning of Mei-long creek. 2005 (In Chinese).

[30] National Land Surveying and Mapping Center, Taiwan (NLSC). 2015. Available online: https://www.nlsc.gov.tw/En. [Accessed 15 September 2015].
[31] Ministry of interior, Taiwan. 2015. Available online: https:// data.moi.gov.tw/MoiOD/Data/DataDetail.aspx? oid=311BDE94-7054-437C-962F-62EA805969B3. [Accessed 15 August 2015]

[32] Council of Agriculture (COA). National Land Surveying and Mapping Center, Taiwan (NLSC). Available online: https:// data.coa.gov.tw/(assessed on 1 December 2015).

[33] Water Resource Agency WRA. Ministry of economic Affairs, (MOEA). 2015. Available online: https://gweb.wra.gov.tw/ HydroInfo/?id=Index. [Accessed 1 October 2015].

[34] Central Geological Survey (CGS). National Land Surveying and Mapping Center, Taiwan (NLSC). Ministry of economic Affairs (MOEA). Available online: https://hydro.moeacgs. gov.tw/map/zh-tw. [Accessed 15 December 2015].

[35] USACE. Hydrologic modeling system (HEC-HMS) application guide: Version 4.3. Davis, CA: Institute for Water Resources, Hydrologic Engineering Center; 2017.

[36] USACE. Geospatial hydrological modeling extension (HECGeoHMS) user manual: Version 10.1. Davis, CA: Institute for Water Resources, Hydrologic Engineering Center; 2013.

[37] USACE. Hydrologic modeling system (HEC-HMS) user's manual: Version 4.3. Davis, CA: Institute for Water Resources, Hydrologic Engineering Center (CEIWR-HEC); 2018.

[38] Neter J, Wasserman W, Kutner MH. Applied statistical models. Burr Ridge, IL: Richard D. Irwin, Inc.; 1990.

[39] Nash JE, Sutcliffe JV. River flow forecasting through conceptual models part I-a discussion of principles. J Hydrol 1970;10:282-90.

[40] Yapo PO, Gupta HV, Sorooshian S. Automatic calibration of conceptual rainfall-runoff models: Sensitivity to calibration data. Hydrol Sci J 1996;181(1-4):23-48.

[41] Gupta HV, Sorooshian S, Yapo PO. Status of automatic calibration for hydrologic models: Comparison with multilevel expert calibration. J Hydrol Eng 1999;4:135-43.

[42] Ibrahim AB, Cordery I. Estimation of recharge and runoff volumes from ungauged catchments in eastern Australia. Hydrol Sci J 1995;40(4):499-515.

[43] Academia Sinica. The topographic map for economic development, Taiwan historic map system in the 20th century. 2010 (In Chinese).

[44] Taiwan Government Report. The assistant system of taiwan typhoon analysis and broadcast. Taiwan: Central Weather Bureau; 2013 (In Chinese). 